\title{
Potential Effects of Four Flaming Gorge Dam Hydropower Operational Scenarios on the Fishes of the Green River, Utah and Colorado
}

Environmental Assessment Division Argonne-National Laboratory

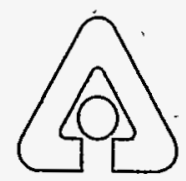

Operated by The University of Chicago, under Contract W-31-109-Eng-38, for the United States Department of Energy DISTRIBUTION OF THIS DOCUMENT IS UNLIMITED 


\section{Argonne National Laboratory}

Argonne National Laboratory, with facilities in the states of Illinois and Idaho,

$\because \quad$ is owned by the United States Government, and operated by the University

$\therefore$ of Chicago under the provisions of a contract with the Department of Energy.

This technical memo is a product of Argonne's Environmental Assessment Division (EAD). For information on the division's scientific and engineering activities, contact:

Director, Environmental Assessment Division

Argonne National Laboratory.

Argonne, Illinois 60439-4815

Telephone (708)-252-3107

Presented in this technical memo are preliminary results of ongoing work or work that is more limited in scope and depth than that described in formal reports issued by the EAD.,

Pablishing support services were provided by Argonne's Information and Publishing Division.

\section{Disclaimer}

"This report was prepared.as an account of work sponsored by an agency of the-United States Government. 'Neither the United States Government nor any agency thereof,'nor any of their employees, makes any warranty, express or implied, or assumes any legal liability or responsibility for the accuracy, completeness, or usefulness of any information, apparatus, product, or procesis disclosed, or'represents that its use would not infringe privately owned rights. Reference herein to any specific commercial product, process, or service by trade name, trademark, manufacturer, or otherwise, does not necessarily constitute or imply its endorsement, recommendation, or favoring by the United States Government or any agency thereof. The views and opinions of authors expressed herein do not necessarily state or reflect those of the United States Govemment or any

-, agency thereof.

Reproduced directly from the best available copy.

Available to DOE and DOE contractors from the Office of Scientific and Technical Information, P.Q. Box 62, Oak Ridge, TN 37831; prices available from (615) $576-8401$.

Available to the public from the National Technical. Information Service, U.S. Department of Commerce, 5285 Port Royal Róad, Springfield, VA 22161. 


\section{Potential Effects of Four Flaming Gorge Dam Hydropower Operational Scenarios on the Fishes of the Green River, Utah and Colorado}

by I. Hohowskyj and J.W. Hayse

Environmental Assessment Division,

Argonne National Laboratory, 9700 South Cass Avenue, Argonne, Illinois 60439

September 1995

Work sponsored by United States Department of Energy, Western Area Power Administration 

This report is printed on recycled paper. 


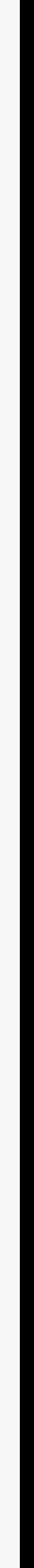




\section{FOREWORD}

This report is one of a series of technical memorandums prepared to support an environmental impact statement (EIS) on power marketing prepared by Argonne National Laboratory for the U.S. Department of Energy's Western Area Power Administration (Western). Western markets electricity produced at hydroelectric facilities operated by the Bureau of Reclamation. The facilities are known collectively as the Salt Lake City Area Integrated Projects (SLCA/IP) and include dams equipped for power generation on the Colorado, Green, Gunnison, and Rio Grande rivers and on Plateau Creek in the states of Arizona, Colorado, New Mexico, Utah, and Wyoming.

Western proposes to establish a level of commitment (sales) of long-term firm electrical capacity and energy from the SLCA/IP hydroelectric power plants; the impacts of this proposed action are evaluated in the EIS. Of the SLCA/IP facilities, only the Glen Canyon Dam, Flaming Gorge Dam, and Aspinall Unit (which includes Blue Mesa, Morrow Point, and Crystal dams) are influenced by Western's power scheduling and transmission decisions. For this reason, the impacts of hydropower operations at these three facilities were examined in the EIS.

The technical memorandums present detailed findings of studies conducted by Argonne National Laboratory specifically for the EIS. These studies are summarized in the EIS, and the results were used to assess environmental impacts related to alternative commitment levels. Technical memorandums were prepared on a number of socioeconomic and natural resource topics. Staff members of Argonne National Laboratory's Decision and Information Sciences Division and Environmental Assessment Division prepared these technical memorandums and the EIS as part of a joint effort managed by the Environmental Assessment Division. 
FOREWORD $\ldots \ldots \ldots \ldots \ldots \ldots \ldots \ldots \ldots \ldots \ldots \ldots \ldots \ldots \ldots \ldots \ldots \ldots \ldots \ldots \ldots$ iii

ABSTRACT $\ldots \ldots \ldots \ldots \ldots \ldots \ldots \ldots \ldots \ldots \ldots \ldots \ldots \ldots \ldots \ldots \ldots \ldots \ldots$

1 INTRODUCTION $\ldots \ldots \ldots \ldots \ldots \ldots \ldots \ldots \ldots \ldots \ldots \ldots \ldots \ldots \ldots \ldots \ldots \ldots$

2 STUDY AREA DESCRIPTION $\ldots \ldots \ldots \ldots \ldots \ldots \ldots \ldots \ldots \ldots \ldots \ldots \ldots$

3 AQUATIC RESOURCES OF CONCERN $\ldots \ldots \ldots \ldots \ldots \ldots \ldots \ldots \ldots$

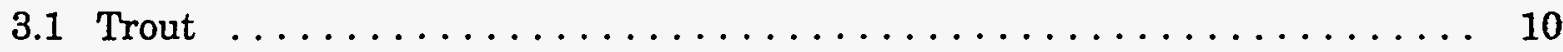

3.2 Native and Introduced Warmwater Species ................. 15

3.2.1 Introduced and Nonendangered Native Species ............ 15

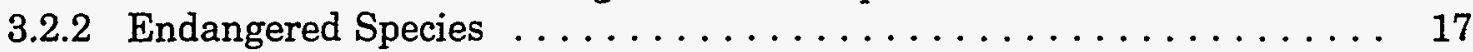

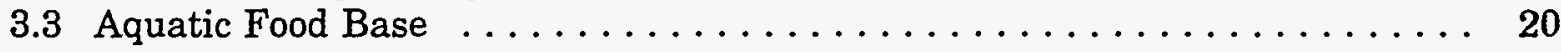

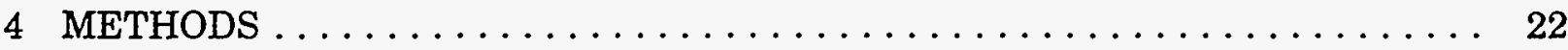

4.1 Aerial Videography $\ldots \ldots \ldots \ldots \ldots \ldots \ldots \ldots \ldots \ldots \ldots \ldots \ldots \ldots \ldots \ldots \ldots \ldots \ldots, 22$

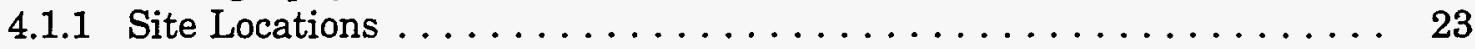

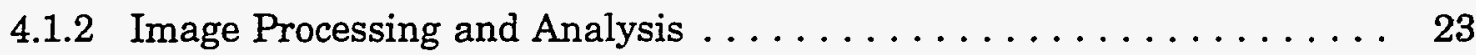

4.2 Operational Scenarios and Hydrological Modeling .............. 24

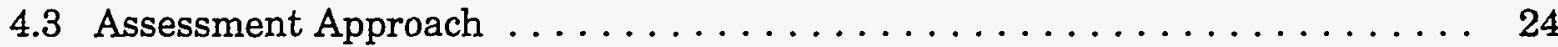

4.3.1 Green River above the Yampa River Confluence ............ 26

4.3.2 Green River below the Yampa River Confluence ........... 27

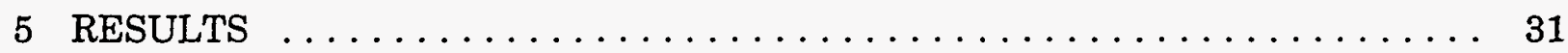

5.1 Surface Water Area .......................... 31

5.2 Areas of the Permanently Wetted, Seasonally Wetted, and Fluctuation Zones $\ldots \ldots \ldots \ldots \ldots \ldots \ldots \ldots \ldots \ldots \ldots \ldots \ldots \ldots \ldots$

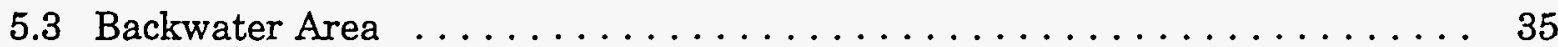

5.4 Daily Fluctuations in Stage $\ldots \ldots \ldots \ldots \ldots \ldots \ldots \ldots \ldots \ldots \ldots \ldots$

5.4.1 Daily Fluctuations at the Red Canyon Tailrace ............. 35

5.4.2 Daily Fluctuations at Jensen $\ldots \ldots \ldots \ldots \ldots \ldots \ldots \ldots \ldots \ldots$

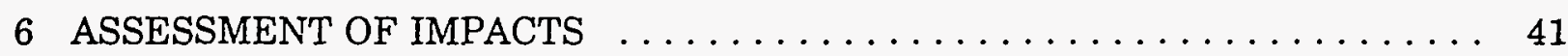

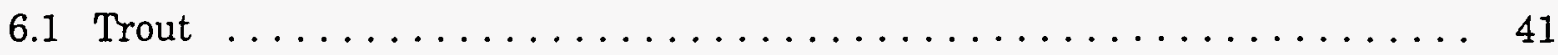

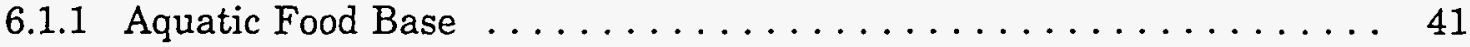

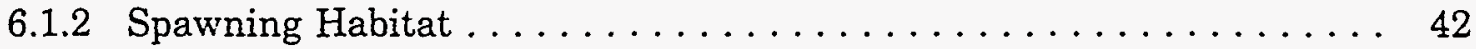

6.1 .3 Overwinter Survival $\ldots \ldots \ldots \ldots \ldots \ldots \ldots \ldots \ldots \ldots \ldots, 42$

6.1 .4 Growth and Condition $\ldots \ldots \ldots \ldots \ldots \ldots \ldots \ldots \ldots \ldots \ldots \ldots$

6.2 Native and Endangered Fishes $\ldots \ldots \ldots \ldots \ldots \ldots \ldots \ldots \ldots \ldots \ldots \ldots \ldots \ldots \ldots \ldots$

6.2 .1 Reproduction .......................... 44

6.2.2 Nursery Habitat Stability, Food Resource

Production, and Recruitment $\ldots \ldots \ldots \ldots \ldots \ldots \ldots \ldots \ldots$ 


\section{CONTENTS (Cont.)}

6.2 .3 Overwinter Survival $\ldots \ldots \ldots \ldots \ldots \ldots \ldots \ldots \ldots \ldots \ldots \ldots$

6.2 .4 Potential Responses of Introduced Fish . . . . . . . . . . . . . 47

7 CONCLUSIONS $\ldots \ldots \ldots \ldots \ldots \ldots \ldots \ldots \ldots \ldots \ldots \ldots \ldots \ldots \ldots$

$8 \quad \operatorname{REFERENCES} \ldots \ldots \ldots \ldots \ldots \ldots \ldots \ldots \ldots \ldots \ldots \ldots \ldots \ldots$

\section{FIGURES}

1 Federally Endangered Fishes of the Upper Green River, Utah

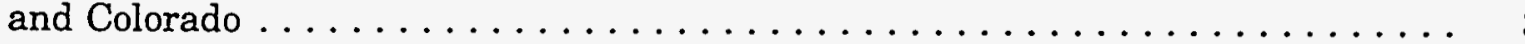

2 Map of the Green River from Flaming Gorge Dam to Jensen, Utah,

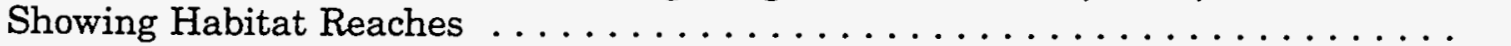

3 Pre-Dam and Post-Dam Flows in the Green River at Greendale

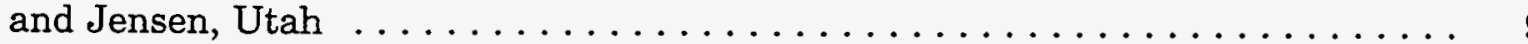

4 Maximum and Minimum Flows for the Flaming Gorge Dam Hydropower Operational Scenarios

5 Aerial Videographic Images of a 0.75-Mile Reach of the Green River Showing Changes in Surface Water Area as River Flow Decreased

6 Typical Backwater Habitat in the Green River at Echo Park, June 1992

7 Ice Cover on the Green River at the Entrance to Split Mountain Canyon, February 1994

8 Areas of Permanently Wetted, Seasonally Wetted, and Fluctuation Zones Estimated for the Flaming Gorge Dam Hydropower Operational Scenarios

9 Minimum and Maximum River Stages at the Red Canyon Tailrace for the Flaming Gorge Dam Hydropower Operational Scenarios

10 Minimum and Maximum River Stages at Jensen for the Flaming Gorge Dam Hydropower Operational Scenarios 


\section{TABLES}

1 Aquatic Habitat Reaches along the Green River from Flaming

Gorge Dam to Jensen, Utah

2 Fish Species in the Green River from Flaming Gorge Dam

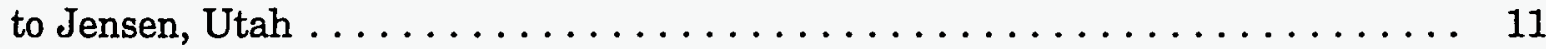

3 Summary of Backwater Habitat Analysis at Island Park in Dinosaur National Monument and at Jensen, Utah, $1987 \ldots \ldots \ldots \ldots .29$

4 Estimated Flow and Surface Water Area at Selected Sites in the Green River, 1992

5 Calculated Surface Water Areas for Different Flows

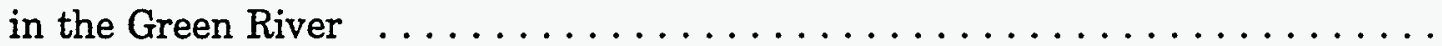

6 On-Peak Duration and Exposure Period for the Flaming Gorge Dam Operational Scenarios during a Moderate Water Year.

7 Predicted Backwater Areas during the Nursery Period for Native and Endangered Fishes in Island Park and at Jensen for the Flaming Gorge Dam Operational Scenarios 


.




\title{
POTENTIAL EFFECTS OF FOUR FLAMING GORGE DAM HYDROPOWER OPERATIONAL SCENARIOS ON THE FISHES OF THE GREEN RIVER, UTAH AND COLORADO
}

by

I. Hohowskyj and J.W. Hayse

\begin{abstract}
Aerial videography and modeling were used to evaluate the impacts of four hydropower operational scenarios at Flaming Gorge Dam, Utah, on trout and native fishes in the Green River, Utah and Colorado. The four operational scenarios studied were year-round high fluctuations, seasonally adjusted high fluctuations, seasonally adjusted moderate fluctuations, and seasonally adjusted steady flows. Impacts on trout were evaluated by examining differences among scenarios in the areas of inundated substrates that serve as spawning and feeding habitat. All scenarios would provide at least 23 acres per mile of habitat for spawning and food production; seasonally adjusted operations would provide additional areas during periods of sustained high release. Seasonally adjusted high fluctuations would increase inundated areas by 12 to $26 \%$ for a short period in winter and spring, but food production and reproduction would not be expected to increase. Seasonally adjusted moderate fluctuations and steady flows would produce similar increases in area, but the longer period of inundation could also result in increased food production and provide additional spawning sites for trout. Impacts on native fishes were assessed by examining daily changes in backwater nursery areas. Compared with year-round high fluctuations, the daily changes in backwater area would decrease by about 47,89 , and $100 \%$ under the seasonally adjusted high fluctuation, moderate fluctuation, and steady flow scenarios, respectively. Similarly, daily stage fluctuations during the nursery period would decrease by 72,89 , and $100 \%$ under the seasonally adjusted high fluctuation, moderate fluctuation, and steady flow scenarios, respectively. These reductions in daily fluctuations in backwater area and stage would improve conditions in nursery habitats and could in turn improve recruitment and overwinter survival. Introduced fish species could also benefit from the seasonally adjusted operational scenarios.
\end{abstract}

\section{INTRODUCTION}

The native fish community of the Colorado River Basin has been adversely affected over the years by human activities. Throughout the basin, construction and operation of 
irrigation and hydropower dams, construction of impoundments, channelization, pollution, diking, water withdrawals, and the introduction of non-native fishes have resulted in major changes in both the physical and biological structure of the river. Physical changes have included altered and more seasonally stable water temperatures, reduced total flows, reduced seasonal but increased daily fluctuations in stream flow, reduced turbidity and sediment transport and increased armoring, elimination of seasonally flooded bottomlands and backwaters, and altered water chemistry. Biological changes have included a dramatic reduction in the distribution and abundance of native fishes; the establishment of coldwater, non-native trout fisheries; changes in the benthic invertebrate community; and dominance of non-native fishes. As a result of these changes, the native fish community of the Colorado River Basin has been greatly reduced, and some fishes are classified as endangered by the federal government. Other native species that have been relatively common until recent years are now being evaluated for potential listing as threatened or endangered species.

Flaming Gorge Dam (and its reservoir) has a strong influence on the physical environment and the fish community of the Green River for about 100 mi downstream of the dam. Prior to construction of the dam, the Green River had turbid waters and a fish community composed of native catostomids and cyprinids, as well as some transplanted cyprinids and salmonids. After the reservoir was filled, one of the best trout fisheries in the western continental United States became established in the tailwaters of the dam. Most native fish species were eliminated from the tailwaters by cold water releases, and these species are currently restricted to areas downstream of the confluence with the Yampa River. The Yampa River is the largest remaining unregulated river in the upper Colorado River Basin, and its inflow into the Green River returns the Green River to more natural conditions.

The Yampa and Green Rivers currently support some of the largest remaining riverine populations of federally endangered ${ }^{*}$ fishes native to the Colorado River system. The lower Yampa River and the Green River from its confluence with the Yampa River to about $100 \mathrm{mi}$ downstream support four endangered native fishes: the Colorado squawfish (Ptychochelius lucius), the razorback sucker (Xyrauchen texanus), the humpback chub (Gila cypha), and the bonytail (Gila elegans) (Figure 1). This portion of the basin has recently been designated by the U.S. Fish and Wildlife Service (USFWS 1994) as critical habitat for the four endangered fishes. In addition, relatively large numbers of other native fishes are present through this reach, including the flannelmouth sucker and roundtail chub, both of which are federal candidates ${ }^{*}$ for listing as threatened or endangered. In 1992, the USFWS issued a Biological Opinion that constrained operations at Flaming Gorge Dam to maintain favorable conditions for these endangered species (USFWS 1992).

\footnotetext{
*A federally endangered species is any species or subspecies of animal or plant whose survival is threatened with extinction throughout all or a significant portion of its range. A federally threatened species is any species that is likely to become an endangered species within the foreseeable future throughout all or a significant portion of its range. A federal candidate species is any species that is not yet officially listed as threatened or endangered but is undergoing status review by the U.S. Fish and Wildlife Service for possible addition to the list of threatened and endangered species.
} 


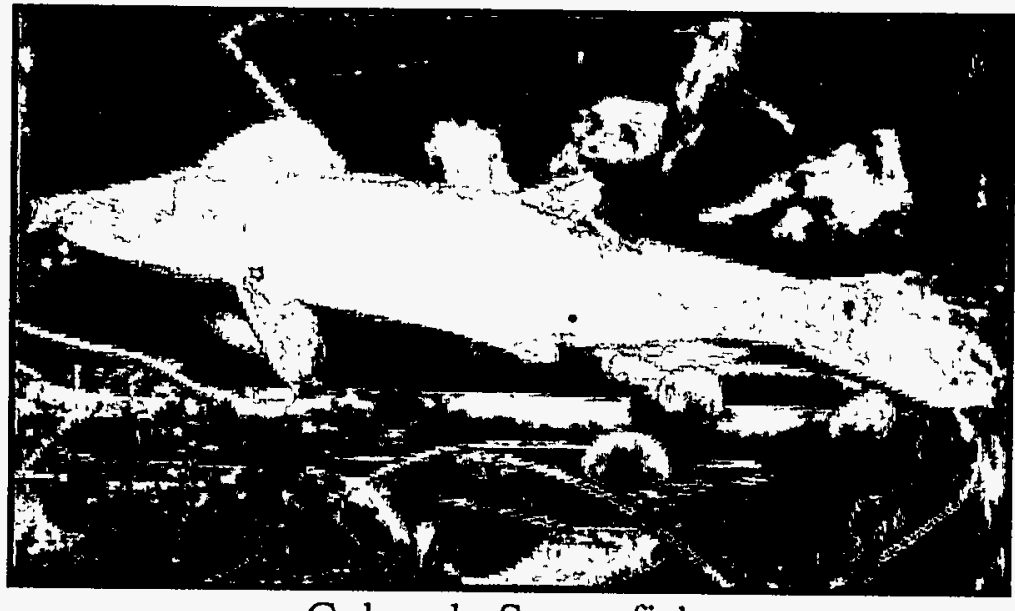

Colorado Squawfish

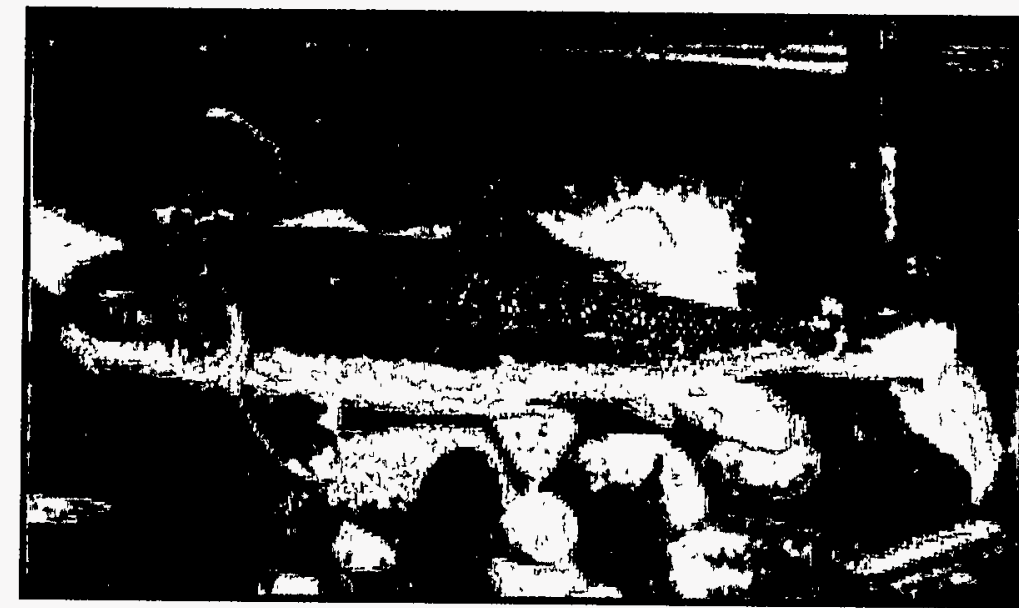

Razorback Sucker

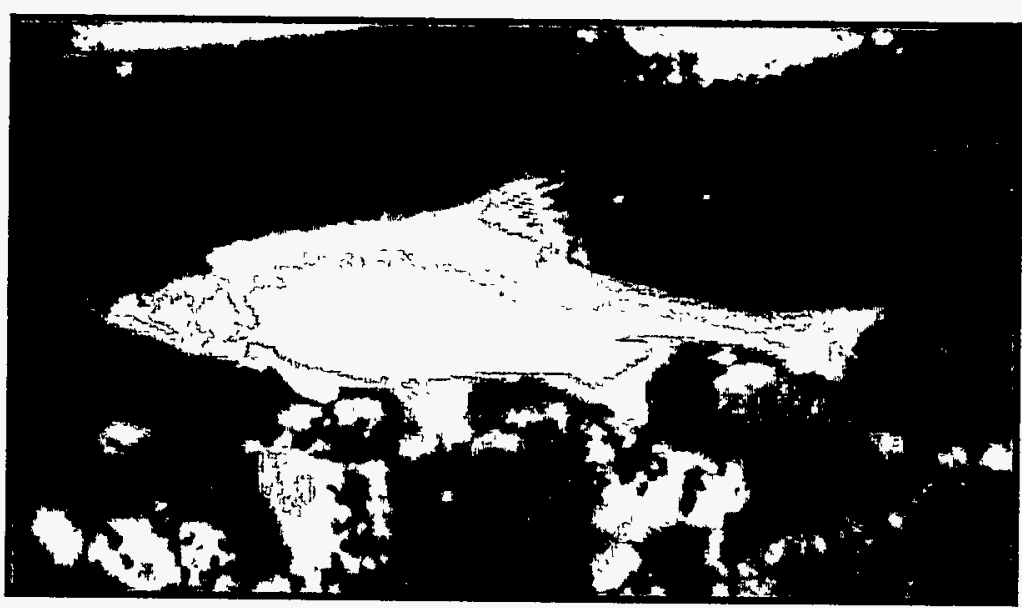

Humpback Chub

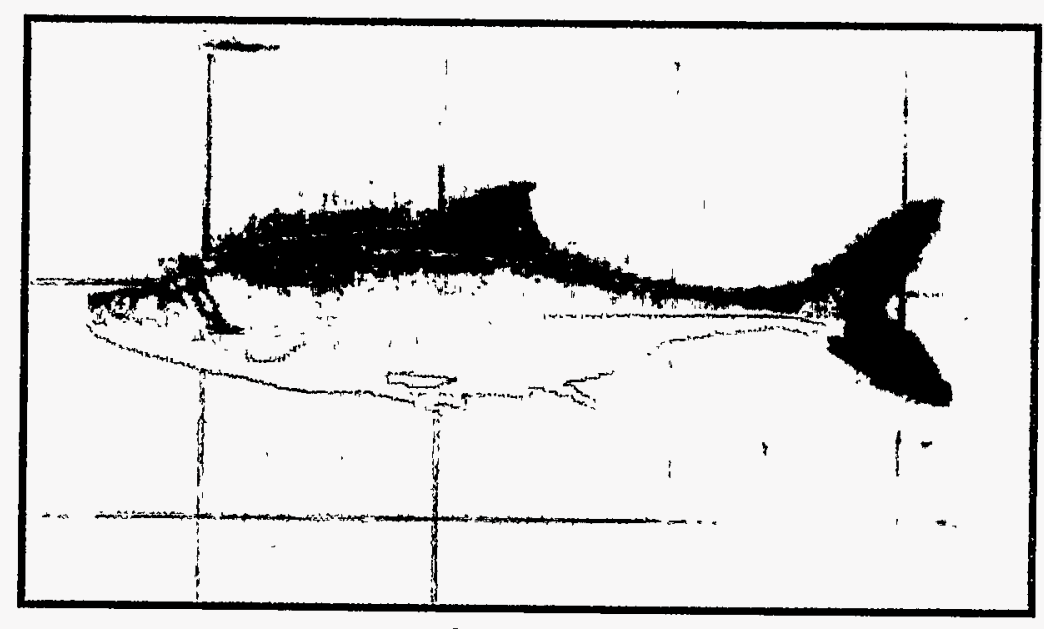

Bonytail

FIGURE 1 Federally Endangered Fishes of the Upper Green River, Utah and Colorado (photographs courtesy of the U.S. Fish and Wildlife Service) 
Hydropower operations at the dam have been implicated in adversely impacting biological resources as far as $90 \mathrm{mi}$ and more downstream of Flaming Gorge Dam (USFWS 1992). Detailed field studies to identify and evaluate potential impacts on fishes were not possible because (1) the potentially affected reach of the Green River is long (>90 mi) and remote; (2) a wide variety of daily and seasonal water release patterns are possible from the dam; and (3) the ability to manipulate water releases from the dam to accommodate studies was limited. Instead, an approach was utilized that combined multispectral aerial videography, hydrologic modeling, and existing ecological information on the biological resources of concern to evaluate the effects of a range of potential hydropower operations. 


\section{STUDY AREA DESCRIPTION}

The Green River occurs within the Green River hydrologic subbasin of the Upper Basin of the Colorado River. This subbasin has a drainage area of about $45,000 \mathrm{mi}^{2}$ in portions of Wyoming, Colorado, and Utah. Flaming Gorge Dam is located on the upper Green River, about $30 \mathrm{mi}$ north of Vernal, Utah. The dam was built to provide water storage and to produce hydroelectric energy. Historically, daily releases from the dam during peaking hydropower operations have ranged from 800 to $4,200 \mathrm{cfs}$; recent upgrades allow maximum releases of $4,700 \mathrm{cfs}$. The evaluation of impacts on the aquatic ecology of the Green River was restricted to the area between Flaming Gorge Dam and the gaging station near Jensen, Utah (Figure 2), because the USFWS Biological Opinion placed restrictions on operations of the facility and compliance with those restrictions results in reduced impacts on areas downstream of the gaging station (USFWS 1992).

For this study, the Green River downstream from Flaming Gorge Dam to Jensen (about $108 \mathrm{mi}$ ) was delineated into approximately 12 reaches of two general types (Figure 2): relatively high-gradient narrow canyon reaches with cobble, boulder, and gravel substrates or low-gradient, meandering alluvial reaches dominated by sand substrates (Table 1). The Yampa River enters the Green River at Echo Park in Dinosaur National Monument, approximately $65 \mathrm{mi}$ below Flaming Gorge Dam (Figure 2). From the dam to Echo Park, the Green River runs cold and clear and has a stage and flow controlled primarily by releases from the dam. In this reach of the Green River, water temperature, sediment load, and stage and flow (Figure 3 ) have been severely altered by historical dam operations.

The Yampa River is the last undammed major river of the Colorado River Basin and is the largest tributary of the Green River. Because of the unregulated nature of the Yampa River, the Green River below Echo Park becomes warmer and more turbid, and exhibits a more natural hydrograph (Figure 3). Upon leaving the Split Mountain area of Dinosaur National Monument (about $90 \mathrm{mi}$ downstream of Flaming Gorge Dam), the Green River enters a wide, cultivated valley where the river is broad and shallow with a meandering channel, low gradient, and relatively calm flows. 


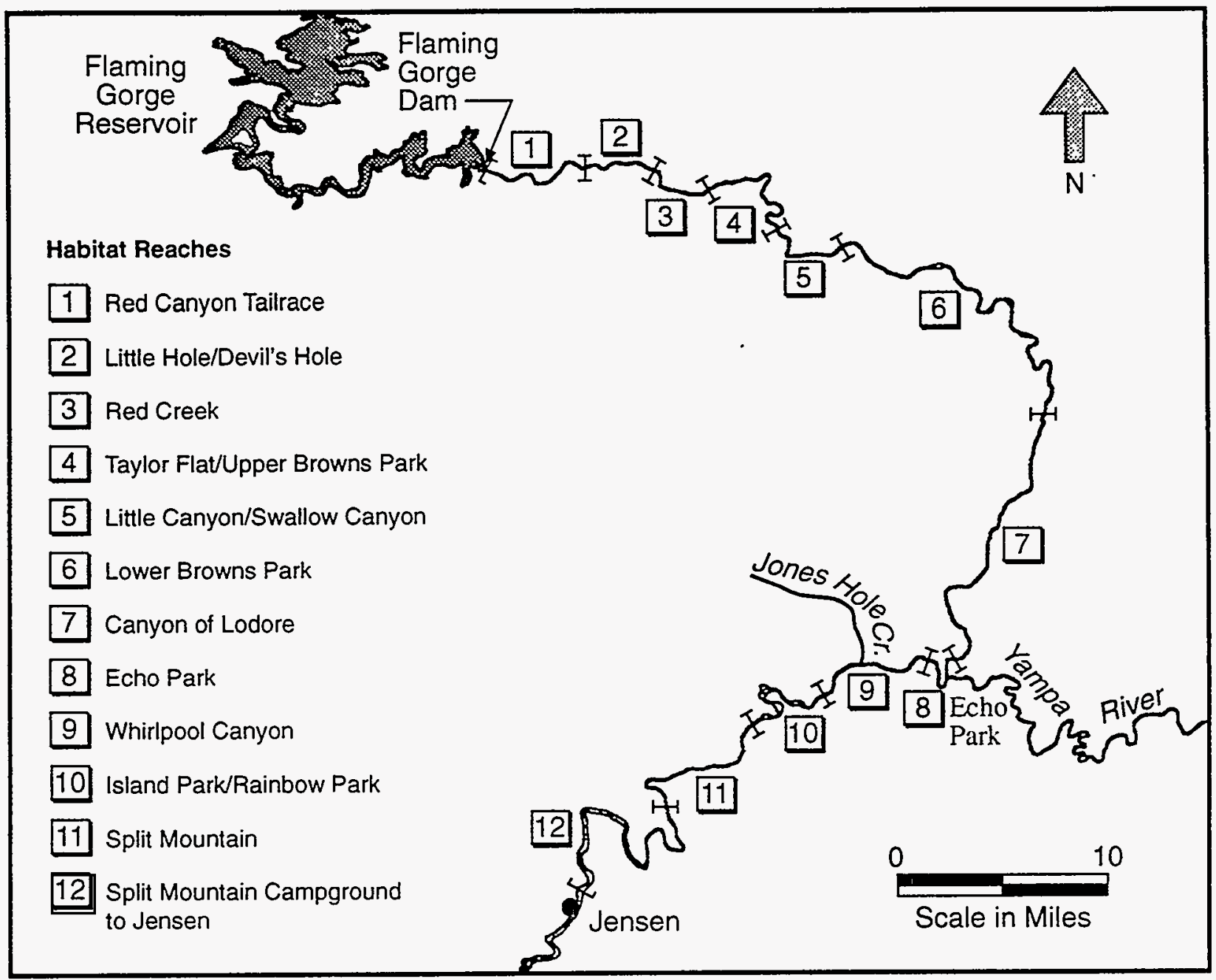

FIGURE 2 Map of the Green River from Flaming Gorge Dam to Jensen, Utah, Showing Habitat Reaches 
TABLE 1 Aquatic Habitat Reaches along the Green River from Flaming Gorge Dam to Jensen, Utah

\begin{tabular}{|c|c|c|c|c|c|c|c|}
\hline & River Reach ${ }^{a}$ & $\begin{array}{l}\text { Miles } \\
\text { from } \\
\text { Dam } \\
\end{array}$ & $\begin{array}{c}\text { Dominant } \\
\text { Macrohabitats }\end{array}$ & $\begin{array}{l}\text { Relative } \\
\text { Current }\end{array}$ & $\begin{array}{l}\text { Shoreline } \\
\text { Substrates }\end{array}$ & $\begin{array}{c}\text { Channel } \\
\text { Substrates }\end{array}$ & Aquatic Habitat \\
\hline 1. & Red Canyon Tailrace & $0-7$ & $\begin{array}{l}\text { Runs, riffles, } \\
\text { rapids }\end{array}$ & High & Boulder, cobble & Boulders, cobble & $\begin{array}{l}\text { Spawning redds for trout, } \\
\text { prime habitat for rainbow } \\
\text { trout }\end{array}$ \\
\hline 2. & $\begin{array}{l}\text { Iittle Hole/Devil's } \\
\text { Hole }\end{array}$ & $7-10$ & Runs, riffles & Moderate & Cobble, pools & Boulders, cobble & $\begin{array}{l}\text { Spawning redds for trout, } \\
\text { prime habitat for rainbow } \\
\text { trout }\end{array}$ \\
\hline 3. & Red Creek & $10-15$ & $\begin{array}{l}\text { Runs, rimles, } \\
\text { rapids }\end{array}$ & High & $\begin{array}{l}\text { Boulders, silt, } \\
\text { gravel, sand }\end{array}$ & Boulders, cobble & Trout habitat \\
\hline 4. & $\begin{array}{l}\text { Taylor Flat/Upper } \\
\text { Browns Park }\end{array}$ & $15-22$ & Runs, rifles & Moderate & $\begin{array}{l}\text { Cobble, sand, } \\
\text { gravel }\end{array}$ & $\begin{array}{l}\text { Cobble, gravel, } \\
\text { sand, silt }\end{array}$ & Trout habitat \\
\hline 5. & $\begin{array}{l}\text { Little Canyond } \\
\text { Swallow Canyon }\end{array}$ & $22-27$ & Runs, pools & Moderate & Sand & Sand & Trout habitat \\
\hline 6. & Lower Browns Park & $27-47$ & $\begin{array}{l}\text { Runs, pools, } \\
\text { many sandbars }\end{array}$ & $\begin{array}{l}\text { Low to } \\
\text { moderate }\end{array}$ & Sand & Sand & Trout habitat \\
\hline 7. & Canyon of Lodore & $47-64$ & $\begin{array}{l}\text { Rapids, runs, } \\
\text { many deep pools }\end{array}$ & High & $\begin{array}{l}\text { Sand and silt along } \\
\text { pools, cobble and } \\
\text { boulders along runs } \\
\text { and rapids }\end{array}$ & $\begin{array}{l}\text { Sand in pools, } \\
\text { cobble in runs and } \\
\text { rapids }\end{array}$ & $\begin{array}{l}\text { Habitat for native fishes, } \\
\text { endangered fishes, and } \\
\text { trout }\end{array}$ \\
\hline 8. & Echo Park & $64-67$ & Runs, riffles & Moderate & Sand, gravel & $\begin{array}{l}\text { Sand, gravel, } \\
\text { some cobble }\end{array}$ & $\begin{array}{l}\text { Habitat for native and } \\
\text { endangered fishes }\end{array}$ \\
\hline 9. & Whirlpool Canyon & $67-76$ & $\begin{array}{l}\text { Runs, rapids, } \\
\text { numerous deep } \\
\text { pools }\end{array}$ & $\begin{array}{l}\text { Moderate to } \\
\text { high, many } \\
\text { eddies }\end{array}$ & $\begin{array}{l}\text { Sand and cobble } \\
\text { along pools and } \\
\text { runs, boulders } \\
\text { along rapids }\end{array}$ & $\begin{array}{l}\text { Sand and silt in } \\
\text { pools, cobble and } \\
\text { boulders in rapids }\end{array}$ & $\begin{array}{l}\text { Native and endangered } \\
\text { fish habitat, spawning } \\
\text { habitat for wild brown } \\
\text { trout (Jones Hole Creek) }\end{array}$ \\
\hline
\end{tabular}


TABLE 1 (Cont.)

\begin{tabular}{|c|c|c|c|c|c|c|c|}
\hline & River Rench ${ }^{a}$ & $\begin{array}{l}\text { Miles } \\
\text { from } \\
\text { Dam }\end{array}$ & $\begin{array}{c}\text { Dominant } \\
\text { Macrohabitats }\end{array}$ & $\begin{array}{l}\text { Relative } \\
\text { Current }\end{array}$ & $\begin{array}{l}\text { Shoreline } \\
\text { Substrates }\end{array}$ & $\begin{array}{c}\text { Channel } \\
\text { Substrates }\end{array}$ & Aquatic Habitat \\
\hline 10. & $\begin{array}{l}\text { Island Park/ } \\
\text { Rainbow I'ark }\end{array}$ & $76-83$ & $\begin{array}{l}\text { Runs, pools, } \\
\text { numerous riffles, } \\
\text { many sand and } \\
\text { gravel bars }\end{array}$ & $\begin{array}{l}\text { Low to } \\
\text { moderate }\end{array}$ & $\begin{array}{l}\text { Gravel and cobble } \\
\text { along riffles, sand } \\
\text { along runs and } \\
\text { pools }\end{array}$ & $\begin{array}{l}\text { Gravel and cobble } \\
\text { along riffles, sand } \\
\text { along runs and } \\
\text { pools }\end{array}$ & $\begin{array}{l}\text { Native and endangered } \\
\text { fish habitat and nursery } \\
\text { areas }\end{array}$ \\
\hline 11. & Split Mountain & $83-90$ & Rapids, runs & High & $\begin{array}{l}\text { Gravel, cobble, } \\
\text { boulders }\end{array}$ & $\begin{array}{l}\text { Gravel, cobble, } \\
\text { boulders }\end{array}$ & $\begin{array}{l}\text { Native and endangered } \\
\text { fish habitat and nursery } \\
\text { areas }\end{array}$ \\
\hline 12. & $\begin{array}{l}\text { Split Mountain } \\
\text { Campground to } \\
\text { Jensen }\end{array}$ & $90-108$ & Runs, pools & $\begin{array}{l}\text { Low to } \\
\text { moderate }\end{array}$ & Sand, gravel & Sand and gravel & $\begin{array}{l}\text { Native and endangered } \\
\text { fish habitat and nursery } \\
\text { areas }\end{array}$ \\
\hline
\end{tabular}

a See Figure 2 for location of river reaches. 

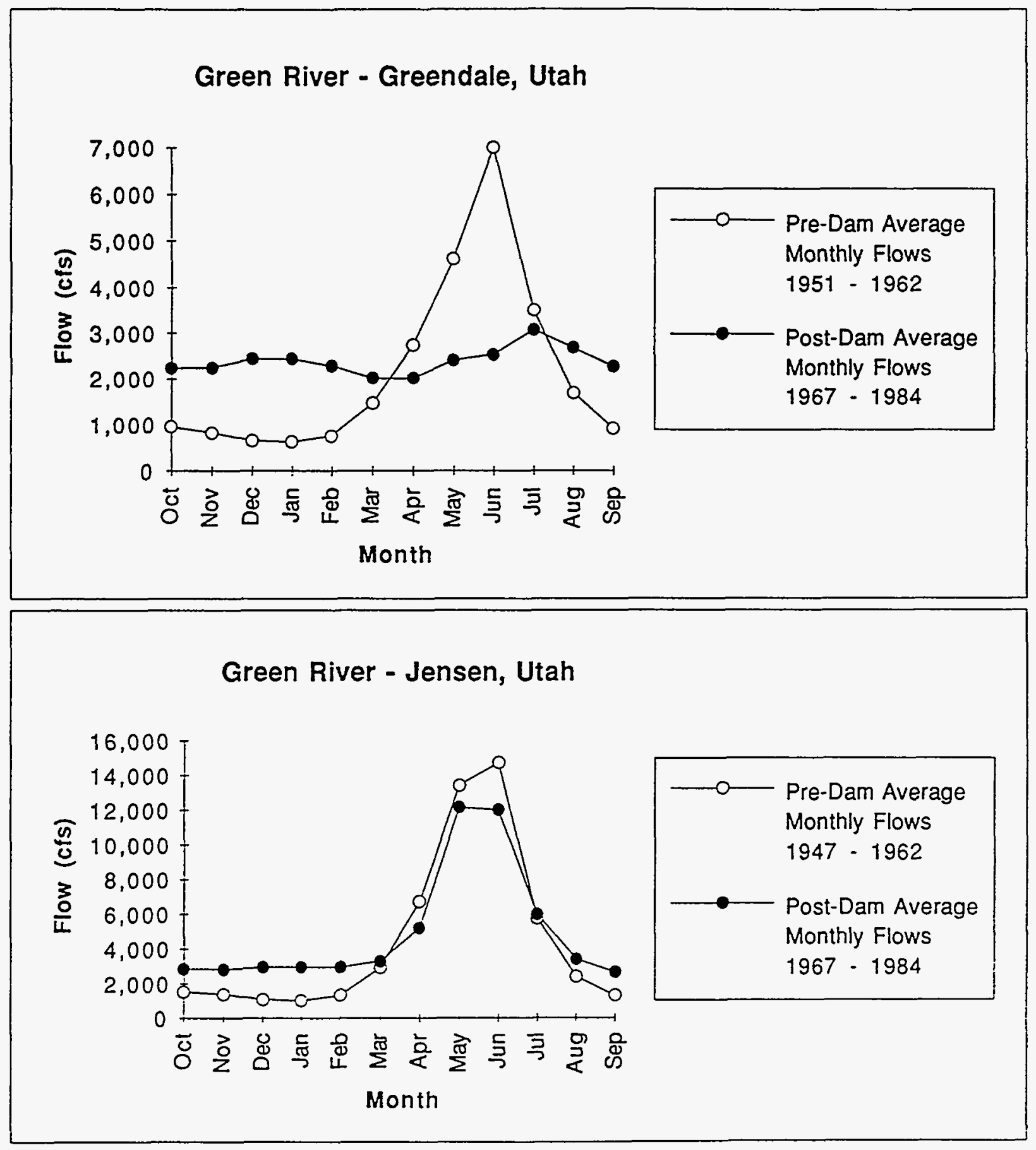

FIGURE 3 Pre-Dam and Post-Dam Flows in the Green River at Greendale $0.5 \mathrm{mi}$ downstream of Flaming Gorge Dam) and Jensen, Utah (94 mi downstream of the dam) (Source: USGS gage data from Smith and Green 1991) 


\section{AQUATIC RESOURCES OF CONCERN}

Thirty-three species of fishes have been reported from the Green River between Flaming Gorge Dam and Jensen and from the very lowermost reach of the Yampa River (Table 2). The fish community below Flaming Gorge Dam - which consists of trout, other introduced fishes, and native species - is strongly affected by water releases from the dam and the inflow of the Yampa River at Echo Park. Above Echo Park, the character of the Green River is strongly affected by the clear, cold water released from the dam, and the fish community in this reach is dominated by trout. Below Echo Park, as the Green River becomes warmer and more turbid because of the inflowing Yampa River, trout become less common and native and introduced warmwater species become the major components of the fish community. The lower reach of the Yampa River includes known spawning sites for razorback sucker, Colorado squawfish, and humpback chub, many of which inhabit the Green River below Echo Park as adults and move into the lower Yampa River to reproduce.

\subsection{TROUT}

The Green River in the tailwaters below Flaming Gorge Dam is considered one of the finest trout fisheries in the western United States. The tailwaters are defined as that portion of the river below a reservoir exhibiting water conditions (such as temperature and clarity) that are very similar to the conditions of the water being withdrawn from the reservoir. The tailwaters below Flaming Gorge Dam extend about 16 river miles (Modde et al. 1991) from the dam to the Taylor Flats area in Browns Park (Figure 2). Previous estimates of trout density in the river directly below the dam and in the vicinity of Little Hole (Figure 2) ranged from 694 to 2,227 fish per hectare and from 458 to 997 fish per hectare, respectively (Modde et al. 1991). The trout community in this area consists of rainbow, brook, and brown trout, as well as several subspecies of cutthroat trout (Table 2).

Studies conducted from 1978 to 1982 by the Bureau of Reclamation and the Utah Division of Wildlife Resources indicated that trout growth rates in the Green River were among the highest reported in North America (Johnson et al. 1987). These same studies also suggested that (1) winter habitat for trout less than 12 in. in length was limited (resulting in greater winter mortality), although there was plentiful habitat for larger trout, (2) the amount of habitat for trout decreased with increasing discharge, and (3) habitat quality and the winter survival of yearling trout declined with increasing distance from the dam (Johnson et al. 1987). On the basis of these conclusions, the Utah Division of Wildlife Resources currently manages the tailwater of Flaming Gorge Dam as a "put and take fishery," with 90,000 to 125,000 fingerling trout stocked annually since 1985 (Modde et al. 1991).

Rainbow, cutthroat, and brook trout are stocked in the river between the dam and Little Hole, and some natural reproduction of these species also occurs in this reach (Modde et al. 1991). Brown trout have not been stocked in the Green River for many years. Trout are usually stocked in April or May at a size of about 6 in., with the goal of stocking fish 
TABLE 2 Fish Species in the Green River from Flaming Gorge Dam to Jensen, Utah

\begin{tabular}{|c|c|c|c|}
\hline Family/Common Name ${ }^{a}$ & Scientific Name ${ }^{a}$ & Origin $^{b}$ & Distribution and Comments ${ }^{c}$ \\
\hline \multicolumn{4}{|l|}{ Salmonidae } \\
\hline Cutthroat trout & Oncorhynchus clarki & $\begin{array}{l}\text { Introduced } \\
\text { and native }\end{array}$ & $\begin{array}{l}\text { Common from dam to Little Hole, decreases } \\
\text { to Echo Park; stocked in tailwaters; prefers } \\
\text { cold, clear headwater streams. Includes the } \\
\text { Colorado River, Snake River, and Bear Lake } \\
\text { subspecies. }\end{array}$ \\
\hline Rainbow trout & Oncorhynchus mykiss & Introduced & $\begin{array}{l}\text { Abundant from dam to Browns Park, common } \\
\text { from Browns Park to Echo Park, rare below } \\
\text { Echo Park; stocked in tailwaters; prefers } \\
\text { pools, eddies, runs, and riffles of streams and } \\
\text { lakes with gravel and cobble substrates. }\end{array}$ \\
\hline Kokanee salmon & Oncorhynchus nerka & Introduced & $\begin{array}{l}\text { Rare; probable escapee from reservoir where } \\
\text { stocked; prefers pelagic zones of reservoirs. }\end{array}$ \\
\hline Mountain whitefish & Prosopium williamsoni & Native & $\begin{array}{l}\text { Rare or incidental below dam, common in the } \\
\text { upper Yampa River; prefers runs with swift } \\
\text { water and gravel and rubble substrates. }\end{array}$ \\
\hline Brook trout & Salvelinus fontinalis & Introduced & $\begin{array}{l}\text { Common from tailrace, decreases in abun- } \\
\text { dance to Echo Park; stocked in tailwaters; } \\
\text { prefers clear headwater areas with gravel } \\
\text { substrate. }\end{array}$ \\
\hline Brown trout & Salmo trutta & Introduced & $\begin{array}{l}\text { Rare in tailrace, becomes more common down- } \\
\text { stream in Browns Park area; prefers deep } \\
\text { pools, riffles. and runs with sand and cobble } \\
\text { substrate and moderate to fast current. }\end{array}$ \\
\hline
\end{tabular}

\section{Cyprinidae}

Red shiner

Common carp

Utah chub

Humpback chub

Bonytail
Cyprinella lutrensis

Cyprinus carpio

Gila atraria

Gila cypha

Native

Introduced

Gila elegans

Introduced

Introduced

(

Rare above Browns Park, common from Browns Park to Echo Park, abundant from Echo Park to Jensen; prefers low-velocity habitats with silt, sand, or boulder substrates.

Abundant from Lodore to Jensen, rare above Lodore, common in lower Yampa River; prefers backwaters, side channels, and inundated areas with silt, sand, or gravel substrates and shorelines with emergent vegetation.

Rare from the dam to Echo Park, incidental in the lower Yampa; prefers littoral and pelagic zones of reservoirs.

Federally endangered; rare from Lodore to Jensen, rare in the lower Yampa; prefers eddy/run interfaces in deep canyon areas with swift currents and boulder and rubble substrates.

Federally endangered; historically present in the upper Green River and at the confluence of the Green and Yampa rivers; last verified specimen from the upper Green River Basin collected in 1979 from the lower Yampa River; prefers eddies and runs in canyon areas with swift current and steep walls. 
TABLE 2 (Cont.)

\begin{tabular}{|c|c|c|c|}
\hline Family/Common Name ${ }^{a}$ & Scientific Name & Origin $^{b}$ & Distribution and Comments ${ }^{c}$ \\
\hline \multicolumn{4}{|l|}{ Cyprinidae (cont.) } \\
\hline Roundtail chub & Gila robusta & Native & $\begin{array}{l}\text { Federal candidate species; abundant from } \\
\text { Browns Park to Island Park, abundant in } \\
\text { Yampa; prefers large river channels with } \\
\text { boulders and overhanging cliffs, usually in } \\
\text { riffles, shallow runs, or eddy/run interfaces. }\end{array}$ \\
\hline Sand shiner & Notropis stramineus & Introduced & $\begin{array}{l}\text { Common around Echo Park and lower Yampa } \\
\text { River, rare below Echo Park; prefers shallow } \\
\text { runs and backwaters with silt and sand } \\
\text { substrates. }\end{array}$ \\
\hline Fathead minnow & Pimephales promelas & Introduced & $\begin{array}{l}\text { Rare from dam to Browns Park, common from } \\
\text { Browns Park to Jensen; prefers backwaters } \\
\text { and pools with silt and sand substrates. }\end{array}$ \\
\hline Colorado squawfish & Ptychocheilus lucius & Native & $\begin{array}{l}\text { Federally endangered; absent above Lodore, } \\
\text { rare from Lodore to Jensen, rare in the lower } \\
\text { Yampa; adults prefer deep runs, eddies, and } \\
\text { large backwaters with silt and boulder sub- } \\
\text { strate; juveniles and young-of-the-year prefer } \\
\text { backwaters with silt and sand substrate. }\end{array}$ \\
\hline Redside shiner & Richardsonius balteatus & Introduced & $\begin{array}{l}\text { Rare from dam to Lodore, common around } \\
\text { Echo Park and the Yampa River; prefers } \\
\text { littoral zones of reservoirs or river } \\
\text { backwaters and pools with slow currents. }\end{array}$ \\
\hline Speckled dace & Rhinichthys osculus & Native & $\begin{array}{l}\text { Rare from dam to Echo Park, common from } \\
\text { Echo Park to Jensen; prefers shallow, swift } \\
\text { runs and riffles with gravel substrates. }\end{array}$ \\
\hline Creek chub & Semotilus atromaculatus & Introduced & $\begin{array}{l}\text { Rare between Browns Park and Jensen, } \\
\text { common around Echo Park; prefers riffles, } \\
\text { runs, and pools with rubble and cobble } \\
\text { substrates. }\end{array}$ \\
\hline
\end{tabular}

\section{Catostomidae}

Utah sucker

White sucker

Bluehead sucker

Flannelmouth sucker

Mountain sucker

Razorback sucker
Catostomus ardens

Catostomus commersoni

Catostomus discobolus

Catostomus latipinnis

Native

Catostomus platyrhynchus

Native

Xyrauchen texanus

Native
Introduced

Introduced Rare above Lodore, common from Lodore to with gravel or cobble substrates.

Federal Category 2; rare above Lodore, common from Lodore to Jensen; prefers runs, shorelines, and eddies of mainstem rivers.

Rare around Echo Park; prefers cool, clear streams with gravel and cobble substrates.

Federally endangered; rare from Lodore to Jensen; spawns in lower Yampa; prefers backwaters, quiet eddies, and deep runs of large river channels. 


\section{TABLE 2 (Cont.)}

\begin{tabular}{|c|c|c|c|}
\hline Family/Common Name ${ }^{a}$ & Scientific Name ${ }^{a}$ & Origin $^{b}$ & Distribution and Comments ${ }^{c}$ \\
\hline \multicolumn{4}{|l|}{ Ictaluridae } \\
\hline Black bullhead & Ameiurus melas & Introduced & $\begin{array}{l}\text { Absent or incidental from dam to Split } \\
\text { Mountain, incidental in upper Yampa River, } \\
\text { rare or incidental in the Green River below } \\
\text { Split Mountain; prefers backwaters with silt } \\
\text { and gravel substrates. }\end{array}$ \\
\hline Channel catfish & Ictalurus punctatus & Introduced & $\begin{array}{l}\text { Rare from dam to Echo Park, common from } \\
\text { Echo Park to Jensen; prefers deep pools, eddies, } \\
\text { shorelines, and runs with silt, gravel, and } \\
\text { boulder substrates or backwaters with silt and } \\
\text { sand substrates. }\end{array}$ \\
\hline
\end{tabular}

\section{Centrarchidae}

Green sunfish

Lepomis cyanellus

Introduced

Rare from Echo Park to Jensen, rare in the lower Yampa River, may be locally common in some reaches; prefers slow-moving stream areas or weed beds of warmwater reservoirs and lakes.

\section{Bluegill}

Smallmouth bass

Largemouth bass
Micropterus dolomieui

Lepomis macrochirus

Micropterus salmoides
Introduced

Incidental at Echo Park; prefers shallow, warm lakes and ponds or slow-moving areas of streams with abundant aquatic vegetation.

Introduced Rare from Echo Park to Jensen, although may be locally common in some reaches; prefers clear, fast-flowing runs and flowing pools with gravel and rubble substrates.

Introduced Incidental in the lower Yampa River; prefers clear, quiet waters with aquatic vegetation or littoral zones of reservoirs and lakes.

\section{Percidae}

Walleye

Stizostedion vitreum

Introduced

Rare from Echo Park to Jensen, incidental in lower Yampa River; prefers large streams, rivers, or lakes with moderately deep water.

\section{Erocidae}

Northern pike

Esox lucius

Introduced

Uncommon in the Yampa River, locally common in the Green River; prefers pools with silt, gravel, or sand and rubble substrates and shallow vegetated areas of lakes.

Cottidae

Mottled sculpin

Cottus bairdi

Native

Rare from dam to Browns Park and below Echo Park, common around Echo Park and lower Yampa River, prefers riffles and deep runs with gravel, rubble, or boulder substrates.

a Source: American Fisheries Society Common and Scientific Names of Fishes (American Fisheries Society 1991).

b Native $=$ a species or subspecies naturally occurring in the upper Green River Basin; Introduced $=$ a species or subspecies that has been introduced into the upper Green River Basin.

c Abundant = occurring in large numbers and consistently collected in a designated area; Common = occurring in moderate numbers and frequently collected in a designated area: Rare = occurring in low numbers, either in a restricted area or hating a sporadic distribution over a larger area; Incidental = occurring in very low numbers and known only from a few collections. Federally endangered and candidate species are defined in footnote on page 2.

Source: Tyus et al. (1982); Haines and Tyus (1990); Karp and Tyus (1990). 
large enough to reach a length of $12 \mathrm{in.} \mathrm{by} \mathrm{winter.} \mathrm{Current} \mathrm{angling} \mathrm{regulations} \mathrm{protect} \mathrm{trout}$ between 13 and $20 \mathrm{in}$. in length and include creel limits for fish outside these slot limits. Under current river conditions and management practices, a "Blue Ribbon" or trophy trout fishery has been established in the Flaming Gorge tailwater (Modde et al. 1991).

The rainbow trout is the dominant trout species from the dam to Little Hole. In this reach, the rainbow trout represents about $50 \%$ of the trout present, and brook and cutthroat trout are the next most abundant, representing about 30 and $12 \%$, respectively of the estimated trout population (Modde et al. 1991). At Little Hole, the brown trout is the second most abundant trout species at $20 \%$ of the trout population, whereas brook and cutthroat trout each comprise no more than $5 \%$ of the trout population. In general, the rainbow, cutthroat, and brook trout decrease in abundance below Little Hole, whereas the brown trout becomes more abundant at the Utah-Colorado state line, about 29 river miles downstream of the dam. Densities of all species decrease in the Green River downstream of its confluence with the Yampa River because of increases in water temperature and turbidity. A localized increase in the density of rainbow and brown trout occurs at the confluence of Jones Hole Creek and the Green River (Figure 2). This creek supports populations of naturally reproducing brown and rainbow trout.

Although the trout fishery below Flaming Gorge Dam is heavily managed through stocking, some natural reproduction and recruitment of trout also occurs. Brown trout and brook trout spawn in the fall, cutthroat trout in spring, and rainbow trout in both seasons. Trout redds occur in the river from immediately below the dam to the Taylor Flat area, whereas brown trout redds have been identified only in reaches downstream of Little Hole. The greatest density of redds occur in the tailrace and between Little Hole and Red Creek (Modde et al. 1991). The rainbow and brown trout have the largest proportion of recruitment from natural reproduction. In 1987 , brown trout accounted for $8.4 \%$ of the young-of-the year trout in study reaches, and rainbow trout accounted for 91.6\% (Modde et al. 1991). In 1988, $57.9 \%$ of the young-of-the-year trout were identified as brown trout and $41.5 \%$ as rainbow trout. Very few young-of-the-year brown trout were captured upstream of Little Hole. Young-of-the-year trout typically inhabit shallow ( $<16$ in. deep) nearshore areas with low water velocity $(<0.33 \mathrm{ft} / \mathrm{s})$.

The penstocks at Flaming Gorge Dam were modified in 1978 to permit selective withdrawal of warmer surface water from the reservoir, increasing river temperatures to levels more optimal for trout production and growth. The modified penstocks allow water to be withdrawn from several reservoir depths, thereby affecting temperatures in the tailrace and beyond. For example, to promote trout growth in summer, water in the reservoir can be withdrawn from nearer the surface, where reservoir temperatures are warmer (57 $\mathrm{F}$ ), and released from the dam to optimize tailwater temperatures for trout (Modde et al. 1991). In winter, water is withdrawn from deep in the reservoir to obtain the warmest $\left(39^{\circ} \mathrm{F}\right)$ available water (Johnson et al. 1987). 


\subsection{NATIVE AND INTRODUCED WARMWATER SPECIES}

Prior to completion of Flaming Gorge Dam, the Green River exhibited seasonal fluctuations in flow, and water temperatures ranged from near freezing to higher than $70^{\circ} \mathrm{F}$ (Holden and Crist 1981). The fish community at this time was composed of both native (including several fishes that are currently classified as endangered) and introduced species, and many of these species were successfully reproducing in the river above its confluence with the Yampa River. Trout were absent from this portion of the river (Holden and Crist 1981). The natural hydrograph of the river prior to construction of the dam exhibited a large spring peak (Figure 3).

To prepare the future Flaming Gorge Reservoir for the establishment of a trout fishery, the Wyoming and Utah Fish and Game Departments, with assistance from the U.S. Fish and Wildlife Service, undertook in 1962 a massive poisoning of approximately $440 \mathrm{mi}$ of the Green River and its tributaries (Holden 1991) to remove "trash" fish such as carp, channel catfish, and redside shiner, as well as native minnows and suckers. Rotenone, a fish poison widely used in fishery management activities, was applied at 55 stations from the headwaters of the Green River in Wyoming to the current location of Flaming Gorge Dam. A problem developed in detoxifying the poison, and some rotenone was transported as far downstream as the lower end of Split Mountain Canyon; dead and dying fish were found along shorelines of Dinosaur National Monument. The poisoning apparently did not kill a large number of currently endangered fishes below the dam, but it did eliminate all such fishes from the Green River above the dam (Holden 1991).

\subsubsection{Introduced and Nonendangered Native Species}

Releases of cold and clear water from Flaming Gorge Dam allowed for the establishment of an outstanding trout fishery but eliminated most if not all successful reproduction by native fishes. Few warmwater fishes occur in the river above the Canyon of Lodore (Figure 2) because of the cold water. The water becomes warmer as it passes

through the Browns Park region, and warmwater fishes occur in the river in the Canyon of Lodore. The controlled releases from the dam also eliminated spring peak flow in the river above Echo Park. Below Echo Park, the river is more similar in temperature and flow to predam conditions because of the input of the Yampa River.

Between the dam and Jensen, 17 introduced fish species (not including salmonids) and 10 native fish species are present in the river (Table 2). Many of the introduced species did not occur in the river prior to completion of the dam. Some species were introduced intentionally, and others were introduced accidentally. The most common introduced species are the channel catfish, carp, fathead minnow, and red shiner (Holden and Crist 1981; Tyus et al. 1982; Karp and Tyus 1990; Haines and Tyus 1990; Tyus and Nikirk 1990). In general, these species are absent or rare from the dam to Browns Park but increase in abundance from Echo Park to Jensen. The fathead minnow and red shiner are very abundant in shoreline habitats around Jensen in summer and autumn, where they have been reported to comprise over $80 \%$ of the fish present in backwater habitats (Haines and Tyus 1990). The 
sand shiner, redside shiner, and creek chub are locally abundant around Echo Park but are rare or absent from the remainder of the river.

Other introduced species are generally present in very low numbers and have relatively limited distributions in the river, although they may be locally abundant in some reaches and habitats. These species include the green sunfish, black bullhead, walleye, bluegill, largemouth bass, smallmouth bass, and northern pike (Table 2). The northern pike is of particular concern because of its possible role as a predator of the endangered fishes in the system. This species was introduced into the Yampa River drainage in 1977 and was first reported from the Green River in 1981 (Tyus and Beard 1990). Although rare or incidental in the Green River, the northern pike may be numerous in quiet-water habitats. The relative absence of most of the introduced species above the Canyon of Lodore (about 47 river miles below the dam) is most likely a result of the cold water temperatures.

Many of the introduced species successfully reproduce in the Green River below Echo Park (Holden and Crist 1981; Grabowski and Hiebert 1989; Haines and Tyus 1990; Tyus and Nikirk 1990). Introduced species dominate the larval fish community in backwaters below Split Mountain (Haines and Tyus 1990). Between the dam and Jensen, neither the northern pike nor the walleye is very successful at reproduction; juveniles and adults apparently enter the system from established, reproductively active populations in the upper Yampa River Basin (Tyus and Beard 1990).

Ten native fish species occur between the dam and Jensen (Table 2); of these, the bluehead sucker and speckled dace are most common. These species are generally rare above the Gates of Lodore and are common or abundant below Echo Park (Holden and Crist 1981; Karp and Tyus 1990). Four of the native species are federally endangered. Three of these species - the razorback sucker, humpback chub, and Colorado squawfish - currently occur in the Green and lower Yampa Rivers. Another federally endangered species, the bonytail, historically occurred in the Green River in Dinosaur National Monument. This species has not been collected or observed from this region since the late 1970s and may be extirpated from the reach.

Although limited reproduction of native species (e.g., the speckled dace) occurs through the Canyon of Lodore to Echo Park, most occurs downstream of Echo Park and in the Yampa River (Holden and Crist 1981). Of the larvae collected in the main channel about $15 \mathrm{mi}$ below Echo Park between 1986 and 1988, 98\% were native fishes - particularly Colorado squawfish, bluehead and flannelmouth suckers, and speckled dace (Haines and Tyus 1990). In contrast to their dominance in the main channel of the Green River below Echo Park, native fishes comprised only about 7\% of the larvae collected between 1979 and 1988 from backwaters between Split Mountain and Desolation Canyon (about 200 mi downstream of Flaming Gorge Dam). Predation and competition from introduced fishes, the loss of historical nursery habitats, and fluctuating flows from hydropower operations have been suggested as causes for the loss of native fish larvae (USFWS 1992). 


\subsubsection{Endangered Species}

\subsubsection{Colorado Squawfish}

The Colorado squawfish was listed as endangered by the USFWS on March 11,1967, and a final recovery plan was approved on August 6, 1991 (USFWS 1991a). Historically, the Colorado squawfish was abundant throughout the big-river portions of the Colorado River Basin but is now absent from the lower basin (USFWS 1991a). Within the upper basin, the Colorado squawfish is considered most abundant in the Green River below Echo Park and in the Yampa River (Tyus and Karp 1991; USFWS 1991a). The decline of the Colorado squawfish has been attributed to alteration and fragmentation of adult habitats by dams, loss of nursery habitats because of dam- and hydropower-induced hydrological changes, depletion of water for irrigation, interactions with introduced fish species, and channelization (USFWS 1991a).

The Colorado squawfish population in the Green River has been estimated to range from about 4,000 to 17,000 adult fish (Tyus 1991). The Colorado squawish is absent from the Green River between Flaming Gorge Dam and the Canyon of Lodore, primarily because of the cold water temperatures and the altered hydrology and physical environment in this reach (USFWS 1991a; Schnurr 1992). Below Echo Park, adult Colorado squawfish occupy a variety of habitats but are most common in eddies, pools, runs, and shoreline backwaters where they utilize low-velocity areas over silt, sand, gravel, and boulder substrates (Tyus and Karp 1991; USFWS 1991a). Young-of-the-year fishes are most abundant in shoreline backwaters (Tyus 1991), concentrating in these nursery habitats in the Island Park and Rainbow Park areas (Figure 2) and near Jensen (Johnson 1992).

Colorado squawfish in the upper Green River spawn over a four- to five-week period between late June and mid August, soon after the peak in spring flows at water temperatures between 64 and $77^{\circ} \mathrm{F}$ (USFWS 1991a). Two major spawning sites have been identified for the Colorado squawfish, one of which is the Yampa River 15 to $31 \mathrm{mi}$ upstream of Echo Park (USFWS 1991a; Johnson 1992). During the spawning season, adult Colorado squawfish in the upper Green River Basin and the Yampa River migrate to the Yampa River spawning ground. Adults have been reported to migrate an average of $73 \mathrm{mi}$ from the Green and Yampa Rivers to the Yampa River spawning ground (Tyus 1990), and they show a fidelity to the Yampa River spawning area year after year (Tyus 1991). Following spawning, adults often return to the river areas they inhabited prior to the spawning migration.

In the lower Yampa River, spawning is believed to occur over gravel, cobble, and boulder bars (Tyus 1990) that are cleared of accumulated sediments during spring floods (Tyus and Karp 1991). Breeding adults concentrate in low-velocity pools and eddies adjacent to the spawning bars, move onto bars to spawn, and then return to pools and eddies. Hatching occurs during declining water levels and increasing water temperatures following peak spring runoff and may last for two to six weeks (Tyus and Haines 1991). Upon hatching, the larval fish are transported as drift downstream from the Yampa River spawning grounds to nursery areas located at Island and Rainbow Parks and in the Jensen 
area. At these nursery areas, the larvae concentrate in backwaters and other nearshore habitats (Tyus and Haines 1991).

Young Colorado squawfish feed primarily on zooplankton and small insect larvae (Grabowski and Hiebert 1989; USFWS 1991a). Juvenile Colorado squawfish become piscivorous very early, with $86 \%$ of their diet being fish. Adult fish are almost exclusively piscivorous, although they have been observed to feed on Mormon crickets and young American coots, and in the past anglers have used jackrabbits, mice, and birds as bait (Tyus 1991; USFWS 1991a).

\subsubsection{Razorback Sucker}

The razorback sucker was listed as endangered by the USFWS on October 23, 1991 (USFWS 1991b). Although once abundant and relatively widespread throughout the Colorado River Basin and the Gila River Basin, this species is now very rare or absent from most of its former range (Bestgen 1990). The largest known existing population occurs in Lake Mohave, Arizona-Nevada, and is estimated at about 60,000 adults (USFWS 1991b).

The upper Green River Basin (including the lower Yampa River) between Echo Park and Desolation Canyon now contains the largest remaining riverine population of razorback suckers, estimated in 1989 to be between about 800 and 1,100 individuals (Lanigan and Tyus 1989). The razorback sucker does not occur in the Green River from Flaming Gorge Dam to the Gates of Lodore (Minckley et al. 1991) but is present in the Green River from the Canyon of Lodore to Jensen and in the lower $13 \mathrm{mi}$ of the Yampa River above Echo Park (Tyus and Karp 1991). This species overwinters in Echo, Island, and Rainbow Parks; in Split Mountain Canyon; and near Jensen (Valdez and Masslich 1989).

The decline of the razorback sucker in the Green River below Flaming Gorge Dam has been attributed primarily to habitat loss due to dam construction, loss of spawning and nursery habitats as a result of diking and dam operations, and alteration of the natural hydrograph (Tyus and Karp 1991). Competition with and predation by introduced fish species have also been identified as important factors in the decline of this species (Bestgen 1990; Minckley et al. 1991; USFWS 1992).

Reproduction in the upper Green River Basin occurs from late April through mid June during peak spring flows at water temperatures between 48 and $63^{\circ} \mathrm{F}$ (Tyus and Karp 1990). Spawning areas have been identified in the lower Yampa River, in the Green River at Echo Park, and between Split Mountain Canyon and Ashley Creek near Jensen, Utah (Tyus and Karp 1990; Schnurr 1992; Johnson 1992). Potential spawning areas have also been identified in Split Mountain Canyon and Island Park (Schnurr 1992).

In the lower Yampa and upper Green Rivers, razorback suckers spawn primarily on riffles with cobble, gravel, and sand substrates (Tyus and Karp 1990). During the spawning season, adults congregate at several locations in the upper Green River, including lower Ashley Creek and Stewart Lake drainages downstream of Dinosaur National Monument 
(Schnurr 1992). Some adults exhibit a spawning migration from the Jensen and Island Park areas to the lower Yampa River, a distance of about 20 to $40 \mathrm{mi}$ (Tyus and Karp 1990). Although successful reproduction occurs in the Green River above Jensen, as evidenced by the presence of larvae, there is currently little recruitment to the adult population (Tyus 1987; Minckley et al. 1991; Tyus and Karp 1991).

Limited information is available on the diet of razorback suckers from the Green River. In other rivers and reservoirs, the razorback sucker has been reported to consume aquatic insects, zooplankton, and algae. Larvae prey on chironomid larvae, algae, and small zooplankton (Bestgen 1990).

\subsubsection{Humpback Chub}

Observed in the wild since the early 1900 s, the humpback chub was not discovered by scientists until 1942 and was not described as a distinct species until 1946 (Carothers and Brown 1991). This species was listed as endangered by the USFWS on March 11, 1967. A recovery plan was approved in 1979, and the second revision of this plan was approved on September 19, 1990 (USFWS 1990b). The historic distribution of the humpback chub probably included much of the Colorado, Green, and Yampa Rivers, and smaller portions of the White and Little Colorado Rivers; today the humpback chub occurs only in restricted portions of its former range (USFWS 1990b).

Below Flaming Gorge Dam, the humpback chub occurs primarily within Dinosaur National Monument in upper Whirlpool Canyon of the Green River (Figure 2) and in the lower Yampa River (Karp and Tyus 1990; USFWS 1990b). The size of the humpback chub population within this reach of the upper Green River Basin is not known, although this chub is most abundant in the lower Yampa River (Karp and Tyus 1990). Within Dinosaur National Monument, adult humpback chub are most prevalent in relatively shallow eddy habitats within high-gradient, whitewater reaches dominated by rocky runs, riffles, and rapids with cobble and sand substrates (USFWS 1990b; Tyus and Karp 1991). Habitat use and requirements of young-of-the-year humpback chub in the Green and Yampa Rivers within Dinosaur National Monument are not known.

Very little is known about the diet of the humpback chub in the Green River below Flaming Gorge Dam, but aquatic insects appear to constitute the bulk of the diet (Karp and Tyus 1990). Also, little is known regarding the flow and habitat requirements for spawning by the humpback chub in either the upper or lower Colorado River Basin.

In the Yampa and Green Rivers within Dinosaur National Monument, successful spawning by the humpback chub is indicated by the collection of juveniles and adults in breeding condition (Karp and Tyus 1990). It is unknown whether spawning is actually occurring in the Green River or whether the reproductive adults collected from the Green River are strays from the Yampa River. Humpback chubs in Dinosaur National Monument spawn in spring and early summer at water temperatures of about $68^{\circ} \mathrm{F}$ (Tyus and Karp 
1991). Reproductive adults are closely associated with shoreline eddies and may return to specific eddies during spawning in different years (Karp and Tyus 1990).

\subsubsection{Bonytail}

The bonytail was listed as endangered by the USFWS on April 23, 1980, and a recovery plan was approved on May 16, 1984. A revised recovery plan was approved on September 4, 1990 (USFWS 1990a). The recovery priority of this species is given as 5C, which indicates a high degree of threat and a low recovery potential for a species that is in conflict with some form of economic activity (USFWS 1990a). Hatchery populations are currently being maintained at the Dexter National Fish Hatchery, New Mexico, and the Willow Beach National Fish Hatchery, Arizona.

The bonytail was collected in the Green River above the Yampa River confluence at Echo Park prior to construction of the Flaming Gorge Dam (Schnurr 1992); it was also collected in moderate numbers below Echo Park after completion of the dam (USFWS 1990a). Since that time, the number of bonytail in the Green and Yampa Rivers within Dinosaur National Monument has declined. Although the last verified bonytail collected from the upper Green River Basin was captured in the lower Yampa River in 1979 (Tyus and Karp 1991), this species is not yet considered extirpated from this region. A suspected individual was collected from the upper Green River in 1987 (Tyus and Karp 1991).

Little is known about the life history of the bonytail, which is generally considered a big-river species. In the Green River, adult bonytail occurred in pools and eddies rather than swifter, main-channel areas, and spawning is believed to have occurred in late spring and early summer at water temperatures of about $64^{\circ} \mathrm{F}$ (USFWS 1990a). Bonytail collected from the Green River in Dinosaur National Monument were found to feed on a variety of aquatic and terrestrial insects.

\subsection{AQUATIC FOOD BASE}

The aquatic food base for fishes in the Green River is dominated by macroinvertebrates and is strongly influenced by flow, available substrates, and the inflow of the Yampa River. Since completion of Flaming Gorge Dam, more than 50 macroinvertebrate types have been recorded from the Green River between the dam and Jensen (Annear 1980; Holden and Crist 1981; Grabowski and Hiebert 1989). The highest macroinvertebrate densities in the Green River occur above its confluence with the Yampa River (Holden and Crist 1981). In the tailwaters and canyon reaches between the dam and Browns Park, the presence of large stable substrates (e.g., boulders) and clear, cold water supports abundant growth of the green alga Cladophora and other attached algae, which provide a food base for a variety of macroinvertebrates. Dominant macroinvertebrates in these areas include Gammarus lacustris, chironomids, and mayfly, blackfly, and caddisfly larvae (Holden and Crist 1981; Gosse 1982; Modde et al. 1991). 
Low-gradient reaches at Browns Park, Island Park, and Rainbow Park and below Split Mountain (Figure 2) generally lack Cladophora, except where occasional rapids and riffles provide suitable hard substrates. The macroinvertebrate community in Browns Park is dominated by chironomids, mayflies, caddisflies, and blackflies (Annear 1980). In Island Park and Rainbow Park, chironomids, oligochaetes, and ceratopogonids (biting midges and sand flies) dominate, representing between 80 and $90 \%$ of the benthic community at some locations (Grabowski and Hiebert 1989). Chironomid and mayfly larvae are the dominant macroinvertebrates present in backwaters in the Jensen area (Holden and Crist 1981; Grabowski and Hiebert 1989). Little is known about the aquatic food base that is present in the tributaries, although it is probably similar to the food base present in the Green River (chironomids, mayflies, and blackflies).

More than 35 types of zooplankton have been reported from the Green River below Echo Park (Grabowski and Hiebert 1989); zooplankton density is generally low in the main channel and in backwaters, although it is greater in backwaters. The density of zooplankton in backwaters also appears to increase in a downstream direction from Island Park. Larger backwaters with narrow connections to the river, and thus with a lower water exchange rate and a greater retention time, generally have higher densities of zooplankton. The zooplankton in these backwater areas are considered an important food resource for a variety of larval and juvenile native and introduced fish species (Grabowski and Hiebert 1989). 


\section{METHODS}

The impacts of four hydropower operational scenarios for Flaming Gorge Dam on trout, native fishes, and endangered fishes were evaluated by examining how discharge and flow would change under each scenario on a seasonal and daily basis. These changes were related to potential impacts on the fish community of the Green River between Flaming Gorge Dam and the gaging station near Jensen, Utah (Figure 2). The four operational scenarios evaluated were year-round high fluctuations, seasonally adjusted high fluctuations, seasonally adjusted moderate fluctuations, and seasonally adjusted steady flows.

The USFWS Biological Opinion has placed restrictions on hydropower operations at Flaming Gorge Dam (USFWS 1992) that specify a large, sustained spring peak and reduced daily flow fluctuations around target flows in the river at Jensen. The operational restrictions are considered necessary by the USFWS to provide adequate spawning cues and conditions in spring and to minimize impacts to larval endangered fishes and their habitats in summer and autumn. Compliance with the Biological Opinion is assumed to be protective of the native and endangered fishes that occur in the Green River downstream of Jensen. Operations of Flaming Gorge Dam must comply with the Biological Opinion, and each of the three seasonally adjusted operational scenarios would meet the flow requirements. The yearround high fluctuating flow scenario does not comply with the Biological Opinion, and thus could not be implemented at the dam; it was evaluated for comparative purposes only. The operational scenarios were also compared with historical operations, which had minimum and maximum flows of 800 and $4,200 \mathrm{cfs}$, respectively.

Two approaches were used to evaluate potential impacts: aerial videography and hydrological modeling (Yin et al. 1995). Both approaches were used to evaluate changes in surface water area in the Green River between the dam and the Yampa River. Below the Yampa River confluence, hydrological modeling (Yin et al. 1995) was used to evaluate the magnitude of daily and seasonal changes in flow and stage in the river. This information in turn was used with flow-habitat relationships developed for Island Park and Jensen (Pucherelli et al. 1990) to evaluate potential changes in backwater nursery habitats under each operational scenario.

\subsection{AERIAL VIDEOGRAPHY}

Multispectral aerial videography was carried out with a system of three video cameras mounted on a fixed-wing aircraft, which simultaneously recorded ground reflectance in three different spectral bands (Neale 1992). Separate video cameras recorded the green $(0.55 \mu \mathrm{m})$, red $(0.65 \mu \mathrm{m})$, and near-infrared $(0.85 \mu \mathrm{m})$ bands of the electromagnetic spectrum. These bands are similar to Landsat Multispectral Scanner red, green, and infrared bands.

Videographic images were collected on four dates from May 15 to June 5, 1992, by flying about 2,000 ft above the river surface at each study site. Videotaping at this altitude provided an image resolution of 0.5 to $1.0 \mathrm{~m}$ per pixel and typically kept both shorelines and 
riparian areas in the fields of view of the cameras. Because of the meandering river channel, weather conditions, and topography, several flight lines were required to videotape each study site. During videography, releases from the dam ranged from approximately 800 to $4,000 \mathrm{cfs}$.

Immediately prior to the first videotaping session, field crews visited each study site to collect site-specific information and to place panel markers that would be used to provide scale measurements during analysis of the imagery. The information gathered included descriptions of each site and the shoreline substrate, as well as measurements of features likely to be visible in the videographic images. The scale markers, which consisted of 2-m $\times 2$-m white plastic panels, were placed approximately $10 \mathrm{~m}$ apart near the shoreline. Photographs and narrated videotapes were also collected at each site to show positioning of the markers and other features of interest, such as vegetation and topographic features. Greater detail of the videographic methods is presented in Snider et al. (1994).

\subsubsection{Site Locations}

The study area encompassed approximately $42 \mathrm{mi}$ of the Green River between the dam and the Canyon of Lodore in Dinosaur National Monument. Four study sites were selected along this portion of the river for the multispectral aerial videographic study. The sites were located at (1) Red Canyon Tailrace, (2) Little Hole/Devil's Hole, (3) Taylor Flat/Upper Browns Park, and (4) Lower Browns Park (Reaches 1, 2, 4, and 6 in Figure 2). The study sites ranged from about 0.6 to $1.4 \mathrm{mi}$ in length and included both canyon and bottomland areas.

\subsubsection{Image Processing and Analysis}

For each site, base maps were digitized with commercially available software from U.S. Geological Survey (USGS) topographic maps at a scale of 1:24,000. Latitude and longitude coordinates recorded on the videotapes were used to locate flight lines on the base maps. Individual overlapping frames covering each flight line were captured from the videotapes and converted to images suitable for use with commercially available imageprocessing software. Details regarding the equipment, image processing, and development and use of supervised classification algorithms are presented in Snider et al. (1994).

During processing, images were captured independently from each of the three videotaped color bands, which were then combined into composite, three-band images for each site. Following completion of image capture and processing, there was a series of overlapping images at each site for four flows. The images for each flow at each site were cropped to produce a series of nonoverlapping images, and supervised classification algorithms were applied to the nonoverlapping images to classify water area at each flow. The supervised classification was performed on the images to classify water areas only. 
Each pixel on the classified images represented a unit area of land or water. The high-flow images were scaled on the basis of the panel markers that were placed at each study site by field crews during the first videotaping flyover. Other site-specific information collected by field crews was also used when available to provide scale information. Following scaling of the high-flow image, the images for the lower flows were scaled to the high flow on the basis of similar features between images.

\subsection{OPERATIONAL SCENARIOS AND HYDROLOGICAL MODELING}

The seasonal hydrographs for the four operational scenarios evaluated are shown in Figure 4. The water release patterns associated with each of these scenarios were determined with the Streamflow Synthesis and Reservoir Regulation (SSARR) computer model (U.S. Army Corps of Engineers 1987) used by the Bureau of Reclamation for the Green River below Flaming Gorge Dam. The hydrographs depicted in Figure 4 were developed by plotting the predicted daily minimum and maximum dam release values.

Each of the seasonally adjusted operational scenarios was developed to comply with the flow restrictions and recommendations identified in the Biological Opinion for the operation of Flaming Gorge Dam (USFWS 1992). The SSARR model was also used to predict flow and stage at intermediate locations between the dam and the USGS gage at Jensen. Details on the SSARR model, development of the operational scenarios, and prediction of flow and stage at selected locations along the Green River are provided in Yin et al. (1995).

\subsection{ASSESSMENT APPROACH}

For this assessment, the Green River was divided into two reaches for analysis: the reach above and the reach below the confluence with the Yampa River. This division was based on the difference in the physical nature of the Green River above and below the Yampa River confluence and on the different biotic resources of concern in these reaches. The Yampa River is the main tributary to the Green River in the study area, and the confluence of the two rivers is about $65 \mathrm{mi}$ downstream of the dam.

Information obtained from aerial videography was used to determine the relationship between flow and water surface area at each study site (Figure 5). Once these relationships were developed, it was possible to evaluate the effects of a full range of possible dam release patterns, ranging from steady flow releases to maximum daily fluctuations.

Predicted instream flows for given dam releases and the derived relationships between water area and flow, backwater area and flow, and stage and flow were used to predict changes in habitat area and stage over one year. These predictions were based upon a moderate water year, with monthly volumes similar to those that occurred in 1987 . Details on 1987 monthly volumes are presented in Yin et al. (1995). The predicted daily maximum and minimum habitat and stage values were plotted to determine habitat area and the 

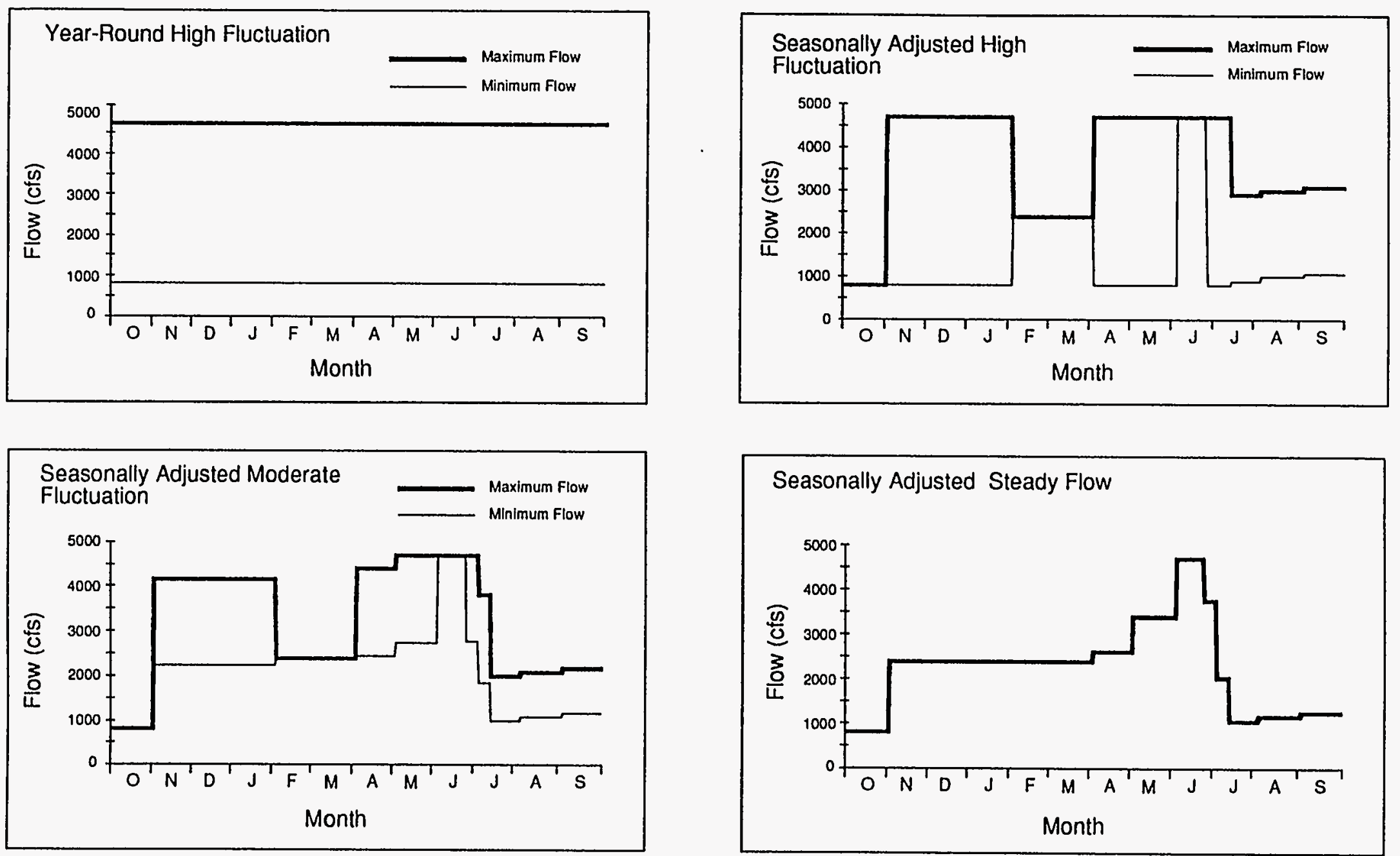

FIGURE 4 Maximum and Minimum Flows for the Flaming Gorge Dam Hydropower Operational Scenarios (Source: Adapted from Yin et al. 1995) 
amount of daily change by month and season. In most cases, knowing the changes to habitat or stage did not allow a direct determination of impacts without a consideration of life history or other specific ecological requirements. For example, trout use of nearshore substrates for spawning had to be taken into account when evaluating impacts of the daily and seasonal changes in substrate exposure.

\subsubsection{Green River above the Yampa River Confluence}

Trout were the resource of primary interest for the Green River above its confluence with the Yampa River. Important factors relative to trout in the Green River include population levels, growth rates, condition factors, food resources, overwinter survival of stocked fishes, and natural reproduction. Impacts on these factors were estimated on the basis of predicted changes in the physical components of the river, specifically surface water area, exposed substrate, and flow duration.

Following completion of all image-capture and processing activities, total surface water area was estimated for each site at each flow (Figure 5). These data were then used to develop the relationships between total surface water area and flow, which in turn were

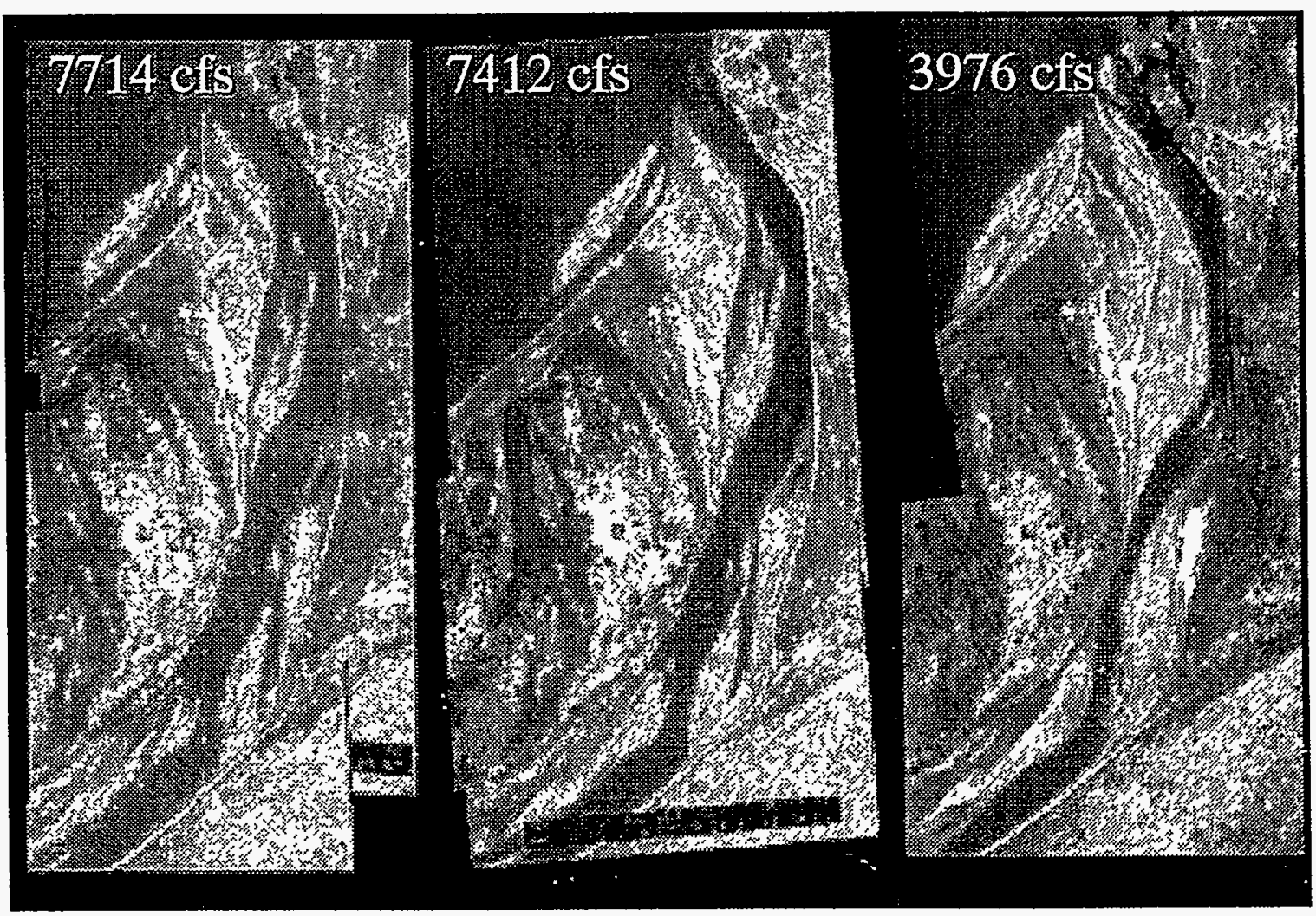

FIGURE 5 Aerial Videographic Images of a 0.75-Mile Reach of the Green River Showing Changes in Surface Water Area as River Flow Decreased 
used to estimate changes in surface water area on a daily and seasonal basis for each operational scenario. The aquatic habitat at each site was delineated into three zones on the basis of the measured and estimated changes in total surface area among the flows: (1) a permanently wetted zone, (2) a seasonally wetted zone, and (3) a daily fluctuation zone.

The permanently wetted zone was defined as the area that would be inundated throughout the year and was determined on the basis of the 800-cfs minimum flow common to all proposed operational scenarios. The permanently wetted zone was assumed to provide the most suitable conditions for establishment of a rich aquatic food base and to provide permanent habitat for foraging, resting, and spawning for trout and other fish species.

The seasonally wetted zone was defined as the area above the 800-cfs level that would be inundated throughout the day for some portion of the year. Because this zone undergoes complete dewatering for an extended length of time, the seasonally wetted zone was considered to support a less productive food base than the permanently wetted area, although some production could occur during certain periods of the year. The seasonally wetted zone was also considered to provide less suitable habitat for successful reproduction of fishes, particularly if the dewatering event coincided with spawning or egg development periods.

The fluctuation zone was considered to be that portion of the aquatic habitat that was subjected to daily flooding and dewatering (exposure). Such areas were assumed to support much less aquatic food production than the seasonally or permanently wetted areas, with the level of production dependent upon the number of hours of exposure. The exposure duration of the fluctuation zone for the tailwaters of Flaming Gorge Dam was estimated by subtracting the on-peak flow (maximum daily flow) duration from 24 hours for each operational scenario. This difference represents the length of time the fluctuation zone would be above the water level each day. For exposure periods greater than 12 hours per day, the productivity of the aquatic food base in the fluctuation zone was considered to be poor (Usher et al. 1987).

\subsubsection{Green River below the Yampa River Confluence}

The primary concerns regarding potential impacts on the fish community in the Green River below its confluence with the Yampa River are the endangered and native fishes, particularly the availability and stability of backwater nursery habitats and overwinter survival. The Biological Opinion on the operation of Flaming Gorge Dam (USFWS 1992) identified target flows to be maintained at the Jensen gage. These target flows (and their stability) are considered of critical importance for the maintenance of suitable nursery habitats for the endangered fishes in the system. Stable backwaters (Figure 6) are assumed to provide optimal temperatures for growth, conditions favorable to a greater production of food for larval fishes, and places of refuge from the strong main channel currents. 


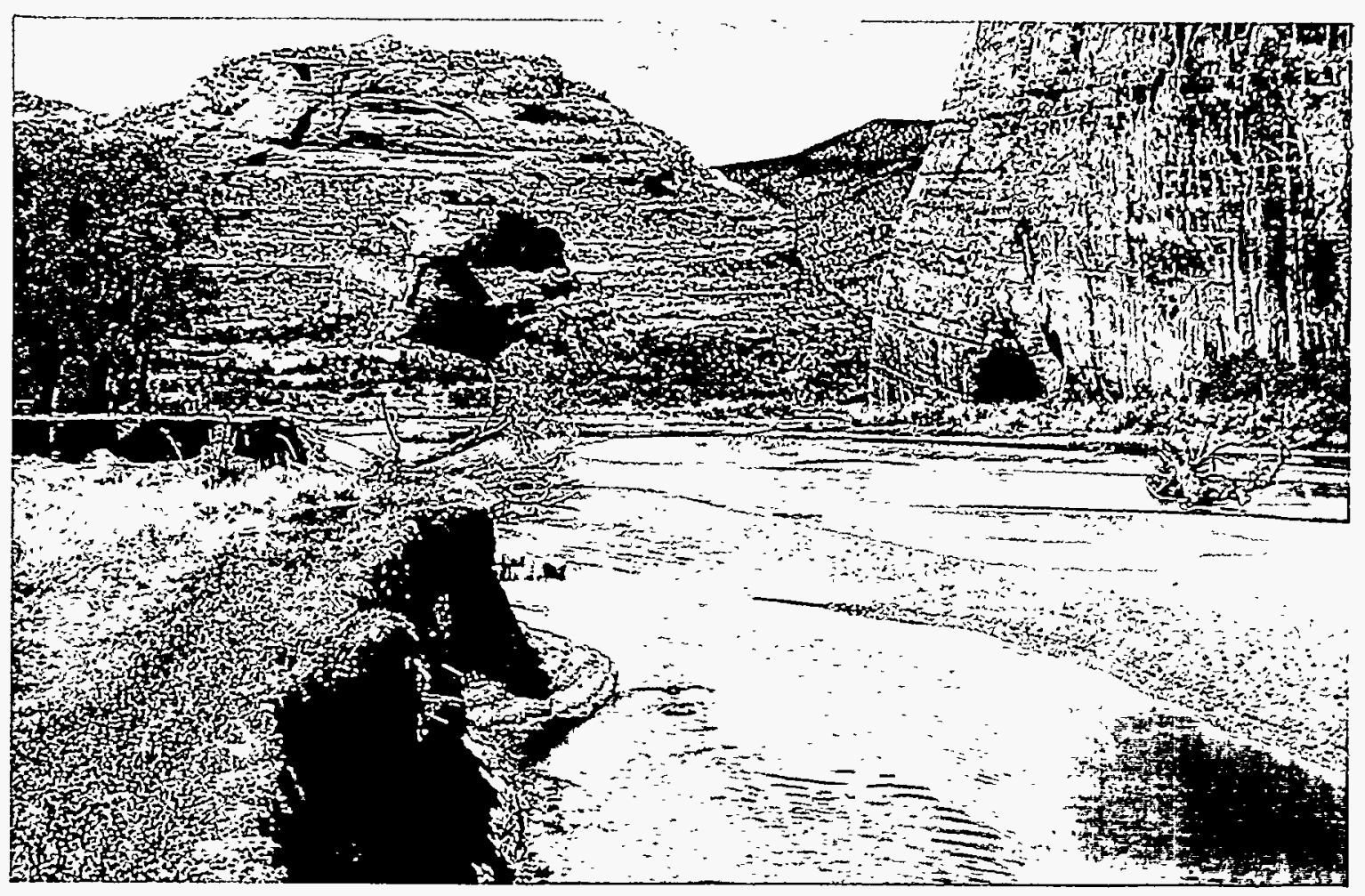

FIGURE 6 Typical Backwater Habitat in the Green River at Echo Park, June 1992

To evaluate the potential impacts of the four hydropower operational scenarios on backwater nursery habitats, the estimated daily changes in stage that could occur in nursery habitat areas in late summer and fall (July 10 through October 31) under each operational scenario were used as indicators of nursery habitat stability and general quality. Because stable backwater habitats potentially have higher, more suitable water temperatures and greater food production than do main channel areas (Grabowski and Hiebert 1989), it was assumed for this assessment that the daily fluctuation in stage was inversely related to the quality of the backwater nursery habitats - that is, the greater the fluctuation, the lower the habitat quality. This decrease in relative quality with greater fluctuation was assumed to result from the daily mixing of cold, relatively nutrient-poor main channel water with the warmer, more nutrient-rich backwaters that would occur with daily stage (and flow) fluctuations. Substrate type also plays an important role in determining backwater quality, but this factor was not evaluated in this assessment.

The effects of the hydropower-induced flows on nursery habitats were further examined by applying the flow-habitat relationships developed by Pucherelli et al. (1990) (Table 3) to the flow regimes predicted by the SSARR model for Island Park and Jensen under each operational scenario. It was assumed that the greater the daily change in backwater availability (expressed as area), the greater the adverse impact of the flow regime. 
TABLE 3 Summary of Backwater Habitat Analysis at Island Park in Dinosaur National Monument and at Jensen, Utah, 1987

\begin{tabular}{cccccc}
\hline $\begin{array}{c}\text { Location/ } \\
\text { Flow } \\
\text { (cfs) }\end{array}$ & $\begin{array}{c}\text { Number of } \\
\text { Backwaters }\end{array}$ & $\begin{array}{c}\text { Backwaters } \\
\text { per Mile }\end{array}$ & $\begin{array}{c}\text { Total } \\
\text { Backwater } \\
\text { Surface Area } \\
\left(\mathrm{ft}^{2}\right)\end{array}$ & $\begin{array}{c}\text { Backwater } \\
\text { Surface Area } \\
\left(\mathrm{ft}^{2} / \mathrm{mi}\right)\end{array}$ & $\begin{array}{c}\text { Average } \\
\text { Surface Area } \\
\text { per Backwater } \\
\left(\mathrm{ft}^{2}\right)\end{array}$ \\
\hline $\begin{array}{c}\text { Island Park } \\
5,014\end{array}$ & & & & & \\
2,507 & 40 & 7.1 & 84,563 & 15,009 & 2,114 \\
1,942 & 32 & 5.6 & 92,267 & 16,147 & 2,883 \\
1,871 & 45 & 7.9 & 120,082 & 21,081 & 2,668 \\
1,624 & 38 & 6.7 & 130,530 & 23,014 & 3,435 \\
1,589 & 41 & 7.2 & 143,635 & 25,224 & 3,503 \\
1,306 & 56 & 9.8 & 215,953 & 37,792 & 3,856 \\
& 52 & 9.2 & 238,366 & 42,172 & 4,584 \\
Jensen & & & & & \\
5,014 & 32 & 4.7 & 83,024 & 12,194 & 2,594 \\
2,507 & 40 & 5.8 & 78,849 & 11,433 & 1,971 \\
1,942 & 48 & 7.1 & 117,757 & 17,418 & 2,453 \\
1,871 & 58 & 8.4 & 137,158 & 19,864 & 2,365 \\
1,624 & 42 & 6.1 & 161,551 & 23,463 & 3,846 \\
1,589 & 46 & 6.7 & 221,322 & 32,236 & 4,811 \\
1,306 & 54 & 7.7 & 204,860 & 29,211 & 3,794 \\
\hline
\end{tabular}

Source: Data from Pucherelli et al. (1990).

High daily flow and stage fluctuations in winter have also been suggested as factors resulting in reduced overwinter survival in native and endangered fishes (Valdez and Masslich 1989). Large daily fluctuations in flow and stage are thought to cause fish to move from areas sheltered from currents to more main channel locations that require greater expenditures of energy because of the high current velocities. High fluctuations in winter are also implicated in the breakup of surface ice (Figure 7), which in turn may physically injure fish as the ice is transported downstream by the river. The potential for reduced overwinter survival from these factors was evaluated by the daily changes in stage and flow that would occur during the overwintering period (December through March) under each operational scenario. It was assumed that the greater the daily fluctuations in stage and flow, the greater the likelihood of increased fish movement and surface ice breakup, both of which could reduce overwinter survival. 


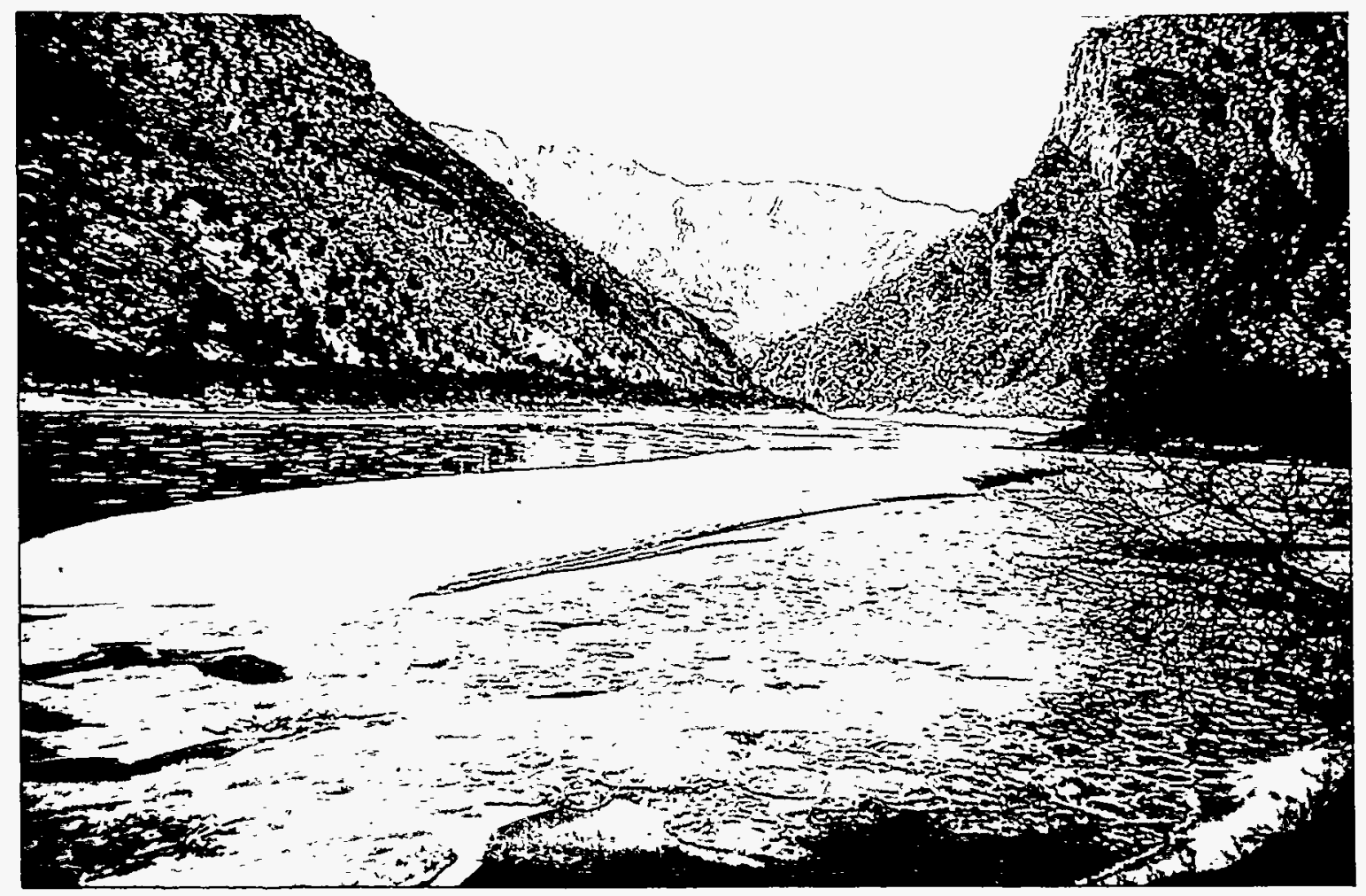

FIGURE 7 Ice Cover on the Green River at the Entrance to Split Mountain Canyon, February 1994 


\section{RESULTS}

\subsection{SURFACE WATER AREA}

The results of the aerial videographic analyses for surface water area in the Green River between Flaming Gorge Dam and the Yampa River confluence are shown in Table 4. At each of the sites, surface water area (acres per mile) increased with increasing flow (cfs), as would be expected, and the relationships were relatively similar among all the sites. An average surface water area to flow relationship was developed for all the sites. These data and the average relationship between flow and surface water area above the 800-cfs water level are presented in Table 5. The surface water area present at the 800-cfs flow represents the permanently wetted zone, and the additional areas present at flows above $800 \mathrm{cfs}$ represent the seasonally wetted and fluctuation zones (as described in Section 4.3.1). The surface water area above the 800-cfs level represents additional potential spawning habitat for trout and other species, foraging habitat for fish, and substrate for the aquatic food base. The average relationships presented in Table 5 were used to estimate the amounts of these parameters that would occur on a daily and seasonal basis under each of the operational scenarios.

\subsection{AREAS OF THE PERMANENTLY WETTED, SEASONALLY WETTED, AND FLUCTUATION ZONES}

The surface water area to flow relationships developed from analysis of the aerial videography were used to estimate the areas of the permanently wetted, seasonally wetted, and fluctuation zones that would occur under each operational scenario. The area of the permanently wetted zone would be identical under all scenarios (Figure 8) because this area is determined by the minimum flow of $800 \mathrm{cfs}$, which is common to all of the scenarios. On the basis of the aerial videography, the permanently wetted habitat present in the Green River from Flaming Gorge Dam to the Yampa River confluence was estimated to average 23.3 acres per mile.

Under the year-round high fluctuating flow scenario, no seasonally wetted zone would occur at any time of the year. Under this scenario, the minimum flow of $800 \mathrm{cfs}$ (Figure 8) from the dam would not change, and the daily flow fluctuations would range from $800 \mathrm{cfs}$ to the maximum power plant release of $4,700 \mathrm{cfs}$ throughout the year (Figure 4). A fluctuation zone of approximately 6.0 acres per mile was estimated for the river under the year-round high fluctuating flow scenario, and the exposure period of this zone would be 12 hours or greater for all periods of the year except November, December, and February; during those months, the exposure time would be 7 to 10 hours (Table 6).

Implementation of the seasonally adjusted high fluctuating flow scenario would result in a seasonally wetted zone of about 2.7 acres per mile in February and March and 
TABLE 4 Estimated Flow and Surface Water Area at Selected Sites in the Green River, 1992

\begin{tabular}{|c|c|c|c|c|c|}
\hline \multirow[b]{2}{*}{ Site } & \multirow{2}{*}{$\begin{array}{l}\text { Site } \\
\text { Length } \\
\text { (mi) }\end{array}$} & \multirow{2}{*}{$\begin{array}{c}\text { Date of } \\
\text { Videography }\end{array}$} & \multirow{2}{*}{$\begin{array}{l}\text { Estimated } \\
\text { Flow } \\
\text { (cfs) }\end{array}$} & \multicolumn{2}{|c|}{ Water Area } \\
\hline & & & & acres & acres/mile \\
\hline \multirow[t]{4}{*}{ Red Canyon Tailrace } & 0.92 & May 15 & 3,823 & 18.4 & 19.9 \\
\hline & & May 17 & 2,427 & 16.8 & 18.2 \\
\hline & & May 20 & 1,442 & 16.7 & 18.1 \\
\hline & & June 5 & 778 & 15.7 & 17.0 \\
\hline \multirow[t]{4}{*}{ Little Hole/Devil's Hole } & 1.37 & May 15 & 3,961 & 38.2 & 27.9 \\
\hline & & May 17 & 2,493 & 33.4 & 24.4 \\
\hline & & May 20 & 1,500 & 30.8 & 22.5 \\
\hline & & June 5 & 795 & 29.5 & 21.6 \\
\hline \multirow[t]{4}{*}{ Taylor Flat/Upper Browns Park } & 0.59 & May 15 & 3,953 & 13.6 & 22.9 \\
\hline & & May 17 & 2,578 & 13.0 & 22.1 \\
\hline & & May 20 & 1,544 & 11.7 & 19.8 \\
\hline & & June 5 & 813 & 11.6 & 19.6 \\
\hline \multirow[t]{4}{*}{ Lower Browns Park } & 0.80 & May 15 & 3,942 & 33.5 & 42.0 \\
\hline & & May 17 & 2,679 & 32.2 & 40.5 \\
\hline & & May 20 & 1,602 & 31.6 & 39.7 \\
\hline & & June 5 & 815 & 27.9 & 35.0 \\
\hline
\end{tabular}

TABLE 5 Calculated Surface Water Areas for Different Flows in the Green River ${ }^{a}$

\begin{tabular}{ccc}
\hline & \multicolumn{2}{c}{ Water Area (acres/mile) } \\
\cline { 2 - 3 } Flow $^{\mathrm{b}}$ (cfs) & Total Area & $\begin{array}{c}\text { Area above } \\
\text { 800-cfs Flow }\end{array}$ \\
\hline & & \\
4,700 & 29.3 & 6.0 \\
4,200 & 28.6 & 5.3 \\
4,000 & 28.3 & 5.0 \\
3,700 & 27.9 & 4.6 \\
3,400 & 27.5 & 4.2 \\
2,500 & 26.2 & 2.9 \\
2,400 & 26.1 & 2.8 \\
1,500 & 24.9 & 1.6 \\
800 & 23.3 & 0.0 \\
\hline
\end{tabular}

a Calculated areas are based on the videographic analyses of four sites in the Green River between Flaming Gorge Dam and the Yampa River confluence.

b See Table 4 for site locations and estimated water surface areas and discharge for each site analyzed by videography.

c The area of inundation at the given flow minus the area of inundation at $800 \mathrm{cfs}$ ( 23.3 acres per mile). 

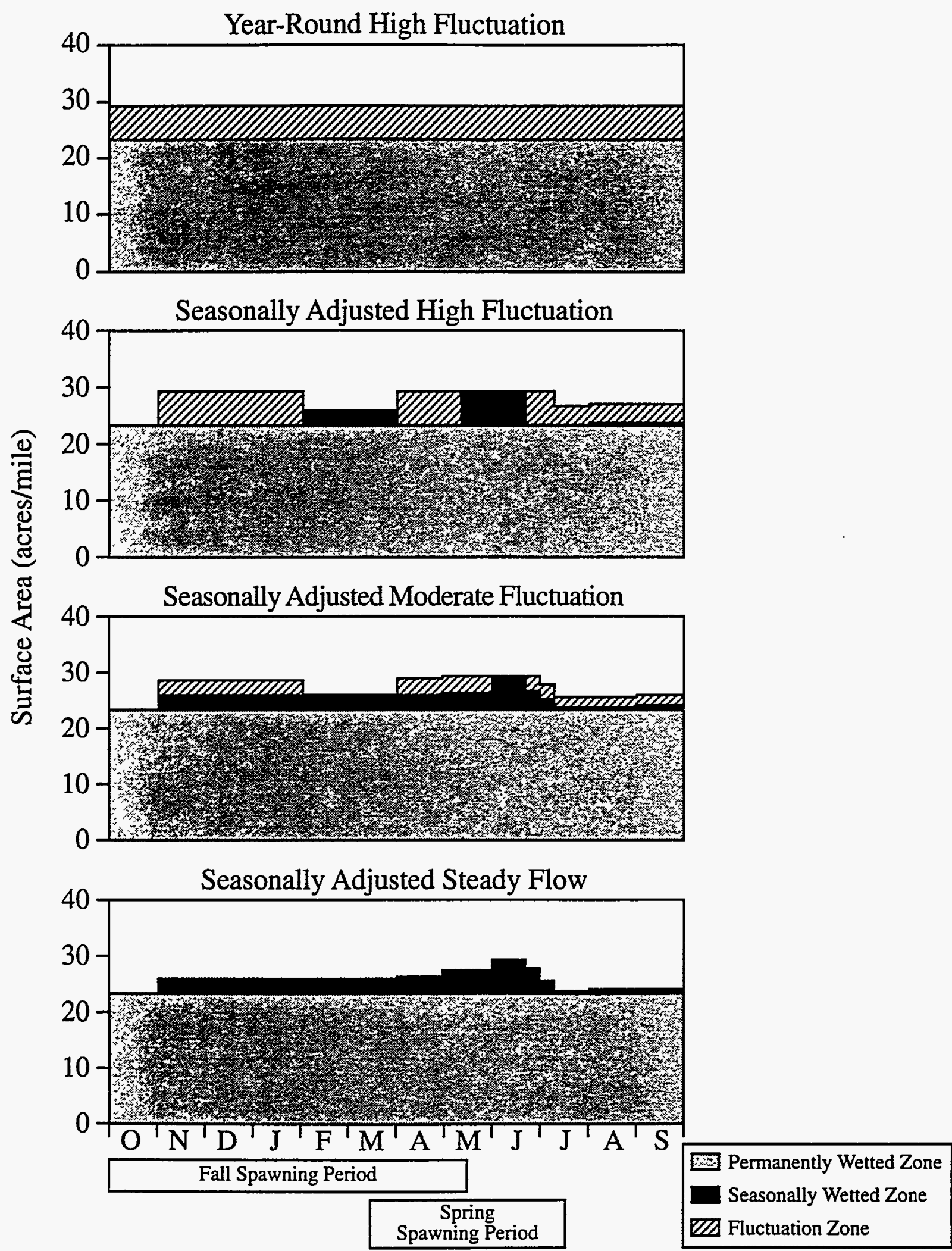

FIGURE 8 Areas of Permanently Wetted, Seasonally Wetted, and Fluctuation Zones Estimated for the Flaming Gorge Dam Hydropower Operational Scenarios 
TABLE 6 On-Peak Duration and Exposure Period for the Flaming Gorge Dam Operational Scenarios during a Moderate Water Year ${ }^{\mathrm{a}}$

\begin{tabular}{|c|c|c|c|c|c|c|}
\hline \multirow[b]{2}{*}{ Period } & \multicolumn{2}{|c|}{$\begin{array}{l}\text { Year-Round High } \\
\text { Fluctuation }\end{array}$} & \multicolumn{2}{|c|}{$\begin{array}{l}\text { Seasonally Adjusted } \\
\text { High Fluctuation }\end{array}$} & \multicolumn{2}{|c|}{$\begin{array}{l}\text { Seasonally Adjusted } \\
\text { Moderate Fluctuation }\end{array}$} \\
\hline & $\begin{array}{c}\text { On-Peak } \\
\text { Duration } \\
\text { (hours) }\end{array}$ & $\begin{array}{c}\text { Exposure } \\
\text { Period } \\
\text { (hours) }\end{array}$ & $\begin{array}{c}\text { On-Peak } \\
\text { Duration } \\
\text { (hours) }\end{array}$ & $\begin{array}{l}\text { Exposure } \\
\text { Period } \\
\text { (hours) }\end{array}$ & $\begin{array}{c}\text { On-Peak } \\
\text { Duration } \\
\text { (hours) }\end{array}$ & $\begin{array}{c}\text { Exposure } \\
\text { Period } \\
\text { (hours) }\end{array}$ \\
\hline October & 10 & 14 & 0 & 0 & 0 & 0 \\
\hline November & 17 & 7 & 9 & 15 & 1 & 23 \\
\hline December & 17 & 7 & 9 & 15 & 1 & 23 \\
\hline January & 12 & 12 & 9 & 15 & 1 & 23 \\
\hline February & 14 & 10 & 24 & 0 & 24 & 0 \\
\hline March & 2 & 22 & 24 & 0 & 24 & 0 \\
\hline April & 2 & 22 & 10 & 14 & 1 & 23 \\
\hline May & 4 & 20 & 15 & 9 & 7 & 17 \\
\hline June 1-21 & 2 & 22 & 24 & 0 & 24 & 0 \\
\hline June $22-30$ & 2 & 22 & 17 & 7 & 11 & 13 \\
\hline July 1-9 & 4 & 20 & 6 & 18 & 1 & 23 \\
\hline July $10-31$ & 4 & 20 & 1 & 23 & 1 & 23 \\
\hline August & 3 & 21 & 1 & 23 & 1 & 23 \\
\hline September & 5 & 19 & 1 & 23 & 1 & 23 \\
\hline
\end{tabular}

a Predictions of monthly volumes were based upon volumes released during 1987. No daily fluctuations in dam releases and, therefore, no exposure of the fluctuation zone would occur under the seasonally adjusted steady flow operational scenario.

Source: Data from Yin et al. (1995).

about 6.0 acres per mile from June 1 to June 21 during the spring peak. Under this scenario, a fluctuation zone of 3.1 to 6.0 acres per mile would occur in early winter and late spring and from early summer through early autumn (Figure 8). Exposure times for the fluctuation zone would range from 7 to 23 hours per day during these periods (Table 6).

The seasonally adjusted moderate fluctuating flow scenario would produce about 2.5 acres of seasonally wetted zone per mile of river from November through May (Figure 8), and this zone would increase to about 6.0 acres per mile in the spring during peak dam releases. A fluctuation zone of 2.7 acres per mile would occur from early winter through mid spring, and a smaller fluctuation zone would occur from early summer through autumn. Any fluctuation zones present under the seasonally adjusted moderate fluctuating flow scenario would be exposed for at least 13 hours per day and typically for more than 20 hours per day (Table 6).

The seasonally adjusted steady flow scenario would produce a permanently wetted zone of approximately 2.7 to 6.0 acres per mile from November through June (Figure 8). No fluctuation zone would occur under this operational scenario. The seasonally wetted zone 
under this scenario would be similar in duration and magnitude to the seasonally wetted zone that would exist under the seasonally adjusted moderate fluctuating flow scenario.

\subsection{BACKWATER AREA}

Backwater areas for the Island Park and Jensen reaches of the Green River (Figure 2) were predicted for each operational scenario on the basis of the backwater areaflow relationships (Table 3) previously developed by the Bureau of Reclamation (Pucherelli et al. 1990). Backwater areas were estimated only for the time period during which these areas are used by native and endangered fishes as nursery habitats (Table 7).

The backwater area would be subject to the greatest daily change under the yearround high fluctuating flow operational scenario for both Island Park and Jensen (Table 7). The backwater area would change daily by about $27,000 \mathrm{ft}^{2} / \mathrm{mi}$ from mid-July through September at Island Park and by about 17,000 $\mathrm{ft}^{2} / \mathrm{mi}$ at Jensen. In October, the backwater area at both locations would be much more constant (Table 7).

Under the seasonally adjusted high fluctuating flow scenario, daily changes in backwater area would be about $17,000 \mathrm{ft}^{2} / \mathrm{mi}$ at Island Park and about 6,900 $\mathrm{ft}^{2} / \mathrm{mi}$ at Jensen for most of the nursery period (Table 7). No backwater area fluctuations would occur at either Island Park or Jensen in October.

Little daily fluctuation in backwater area would be expected under the seasonally adjusted moderate fluctuating flow scenario. Daily fluctuations in area would be less than $3,300 \mathrm{ft}^{2} / \mathrm{mi}$ at Island Park and less than $1,900 \mathrm{ft}^{2} / \mathrm{mi}$ at Jensen (Table 7), and the backwater area would be constant at both sites in October.

No daily fluctuations in backwater area would be expected at either Island Park or Jensen under the seasonally adjusted steady flow scenario (Table 7). Backwater area at Island Park would be greatest under the seasonally adjusted moderate and steady flow operational scenarios (Table 7). During the nursery period, the backwater area at Jensen would differ by only about $1,000 \mathrm{ft}^{2} / \mathrm{mi}$ between these two scenarios.

\subsection{DAILY FLUCTUATIONS IN STAGE}

\subsubsection{Daily Fluctuations at the Red Canyon Tailrace}

The predicted stage changes for the minimum and maximum flows in the Flaming Gorge Dam tailrace are shown in Figure 9. Daily stage changes in river reaches downstream of the tailrace (such as Little Hole or Browns Park) would be expected to be lower due to natural attenuation. Under the year-round high fluctuating flow scenario, river stage in the tailrace would change by approximately $5 \mathrm{ft}$ on a daily basis throughout the year. 
TABLE 7 Predicted Backwater Areas during the Nursery Period for Native and Endangered Fishes in Island Park and at Jensen for the Flaming Gorge Dam Operational Scenarios

\begin{tabular}{|c|c|c|c|c|}
\hline \multirow[b]{3}{*}{ Period } & \multicolumn{4}{|c|}{ Predicted Backwater Area $\left(\mathrm{ft}^{2} / \mathrm{mi}\right)$} \\
\hline & \multicolumn{2}{|c|}{$\begin{array}{c}\text { Year-Round } \\
\text { High Fluctuation }\end{array}$} & \multicolumn{2}{|c|}{$\begin{array}{l}\text { Seasonally Adjusted } \\
\text { High Fluctuation }\end{array}$} \\
\hline & Low Flow & High Flow & Low Flow & High Flow \\
\hline \multicolumn{5}{|l|}{ Island Park } \\
\hline $\begin{array}{l}\text { July 10-31 } \\
\text { August } \\
\text { September } \\
\text { October }\end{array}$ & $\begin{array}{l}41,955 \\
43,813 \\
44,122 \\
18,129\end{array}$ & $\begin{array}{l}15,860 \\
16,073 \\
15,778 \\
14,870\end{array}$ & $\begin{array}{l}41,801 \\
41,801 \\
41,801 \\
22,769\end{array}$ & $\begin{array}{l}24,633 \\
24,544 \\
24,455 \\
22,769\end{array}$ \\
\hline \multicolumn{5}{|l|}{ Jensen } \\
\hline $\begin{array}{l}\text { July } 10-31 \\
\text { August } \\
\text { September } \\
\text { October }\end{array}$ & $\begin{array}{l}29,681 \\
28,291 \\
28,184 \\
13,519\end{array}$ & $\begin{array}{l}11,607 \\
11,464 \\
11,656 \\
12,281 \\
\ldots \ldots \ldots \ldots\end{array}$ & $\begin{array}{l}29,574 \\
29,467 \\
29,467 \\
19,554\end{array}$ & $\begin{array}{l}22,647 \\
22,501 \\
22,501 \\
19,554 \\
\cdots \ldots \ldots \ldots\end{array}$ \\
\hline \multirow{2}{*}{ October } & \multicolumn{4}{|c|}{ Predicted Backwater Area $\left(\mathrm{ft}^{2} / \mathrm{mi}\right)$} \\
\hline & \multicolumn{2}{|c|}{$\begin{array}{c}\text { Seasonally Adjusted } \\
\text { Moderate Fluctuation }\end{array}$} & \multicolumn{2}{|c|}{$\begin{array}{c}\text { Seasonally Adjusted } \\
\text { Steady Flow }\end{array}$} \\
\hline Period & Low Flow & High Flow & \multicolumn{2}{|c|}{ Daily Flow } \\
\hline \multicolumn{5}{|l|}{ Island Park } \\
\hline $\begin{array}{l}\text { July } 10-31 \\
\text { August } \\
\text { September } \\
\text { October }\end{array}$ & $\begin{array}{l}40,562 \\
40,562 \\
40,717 \\
22,769\end{array}$ & $\begin{array}{l}37,433 \\
37,433 \\
37,433 \\
22,769\end{array}$ & & $\begin{array}{l}, 402 \\
402 \\
448 \\
769\end{array}$ \\
\hline \multicolumn{5}{|l|}{ Jensen } \\
\hline $\begin{array}{l}\text { July } 10-31 \\
\text { August } \\
\text { September } \\
\text { October }\end{array}$ & $\begin{array}{l}30,322 \\
30,322 \\
30,322 \\
19,554\end{array}$ & $\begin{array}{l}32,140 \\
31,985 \\
31,985 \\
19,554\end{array}$ & & $\begin{array}{l}124 \\
124 \\
092 \\
554\end{array}$ \\
\hline
\end{tabular}



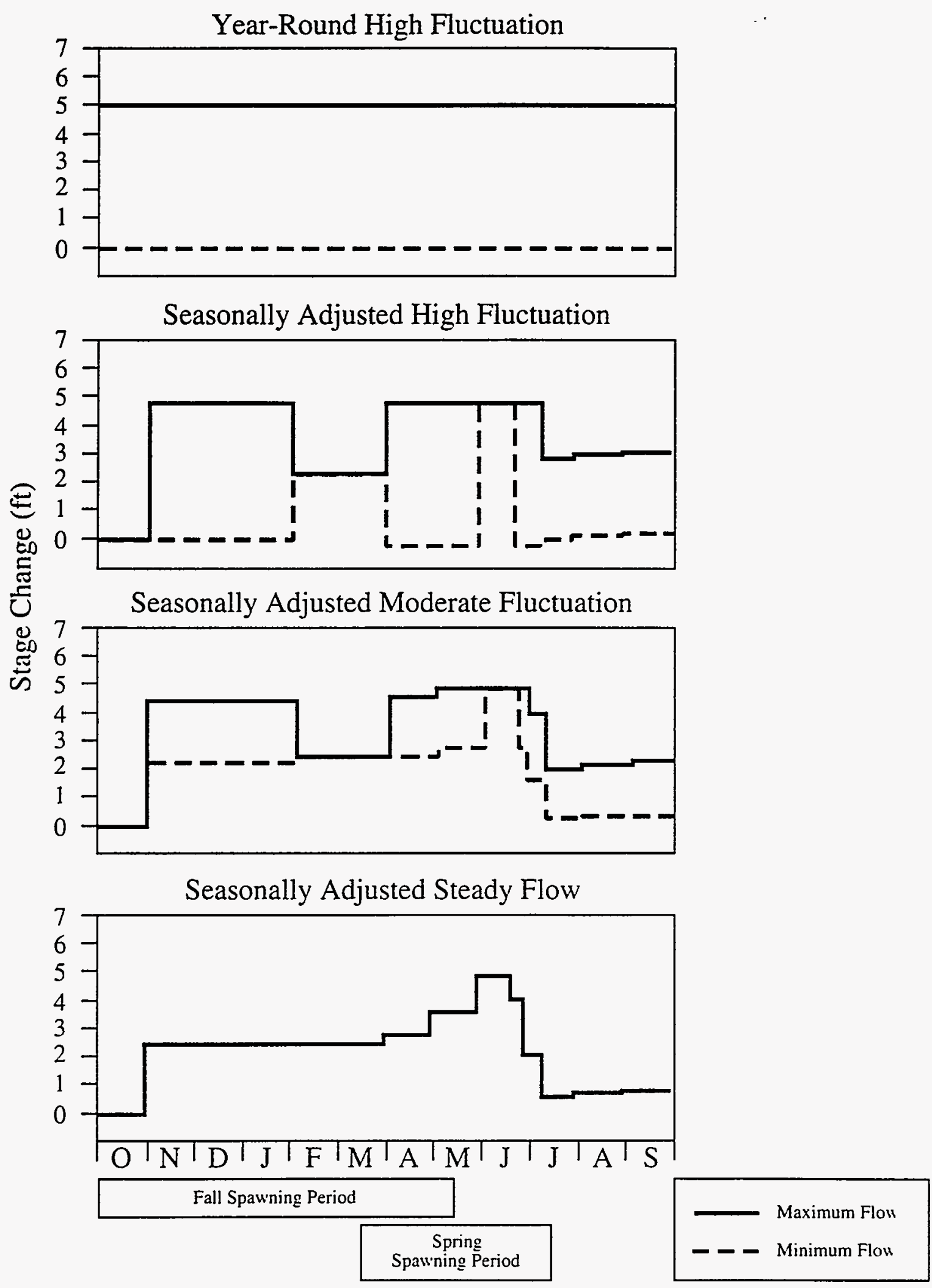

FIGURE 9 Minimum and Maximum River Stages at the Red Canyon Tailrace for the Flaming Gorge Dam Hydropower Operational Scenarios (Source: Adapted from Yin et al. 1995) 
Implementation of the seasonally adjusted high fluctuating flow scenario would result in stage changes of $5 \mathrm{ft} / \mathrm{d}$ from November through January, April through mid May, and early June (Figure 9). The daily stage changes at these times would be similar to the stage changes predicted for these time periods under the year-round high fluctuating flow scenario, and these changes would occur in both the spring and fall spawning periods. Compared to the year-round high fluctuating flow scenarios, daily stage changes under the seasonally adjusted high fluctuating flow scenario would be reduced to no more than approximately $3 \mathrm{ft} / \mathrm{d}$ from late July through September. No daily stage changes would occur from February through March, nor during the time of the sustained spring release from the dam (Figure 9).

Stage changes would be limited to no more than $2.5 \mathrm{ft} / \mathrm{d}$ at any time of the year under the seasonally adjusted moderate fluctuating flow scenario, and no daily stage changes would be expected in October or from February through March (Figure 9). No daily fluctuations in stage would be expected under the seasonally adjusted steady flow scenario. For historical operations, the daily stage changes in the tailrace would be expected to have a seasonal pattern similar to that predicted for the year-round high fluctuating flow scenario. However, the maximum dam release under historical operations $(4,200 \mathrm{cfs})$ was lower than under the year-round high fluctuating flow scenario $(4,700 \mathrm{cfs})$. Thus, the daily stage change was lower under historical operations than would occur under the year-round high fluctuating flow scenario.

\subsubsection{Daily Fluctuations at Jensen}

The predicted stages for the minimum and maximum flows at Jensen are shown in Figure 10. The predicted maximum daily stage changes at Jensen under the year-round high fluctuating flow scenario would range from about 0.6 to $1.8 \mathrm{ft} / \mathrm{d}$ and would be highest in autumn and winter. The daily stage changes predicted for this scenario during the late summer and autumn nursery period (July 10 through September) are the highest of all the operational scenarios (Figure 10).

Under the seasonally adjusted high fluctuating flow scenario, stage changes would range from 0 to $2.2 \mathrm{ft} / \mathrm{d}$ (Figure 10). This scenario would produce the highest winter, midspring, and early summer daily stage changes among the operational scenarios. The maximum predicted daily stage change during the nursery period would be less than $0.5 \mathrm{ft} / \mathrm{d}$.

Under the seasonally adjusted moderate fluctuating flow scenario, the maximum daily stage change predicted for Jensen would not exceed $1 \mathrm{ft} / \mathrm{d}$ and, for most of the year, would typically be less than about $0.2 \mathrm{ft} / \mathrm{d}$ (Figure 10). During the nursery period, predicted maximum daily stage changes would not exceed $0.2 \mathrm{ft} / \mathrm{d}$.

Because no daily fluctuations in dam releases would occur under the seasonally adjusted steady flow scenario, no daily stage changes would be expected for this scenario (Figure 10). Some daily changes in stage would occur at Jensen under this and all other 

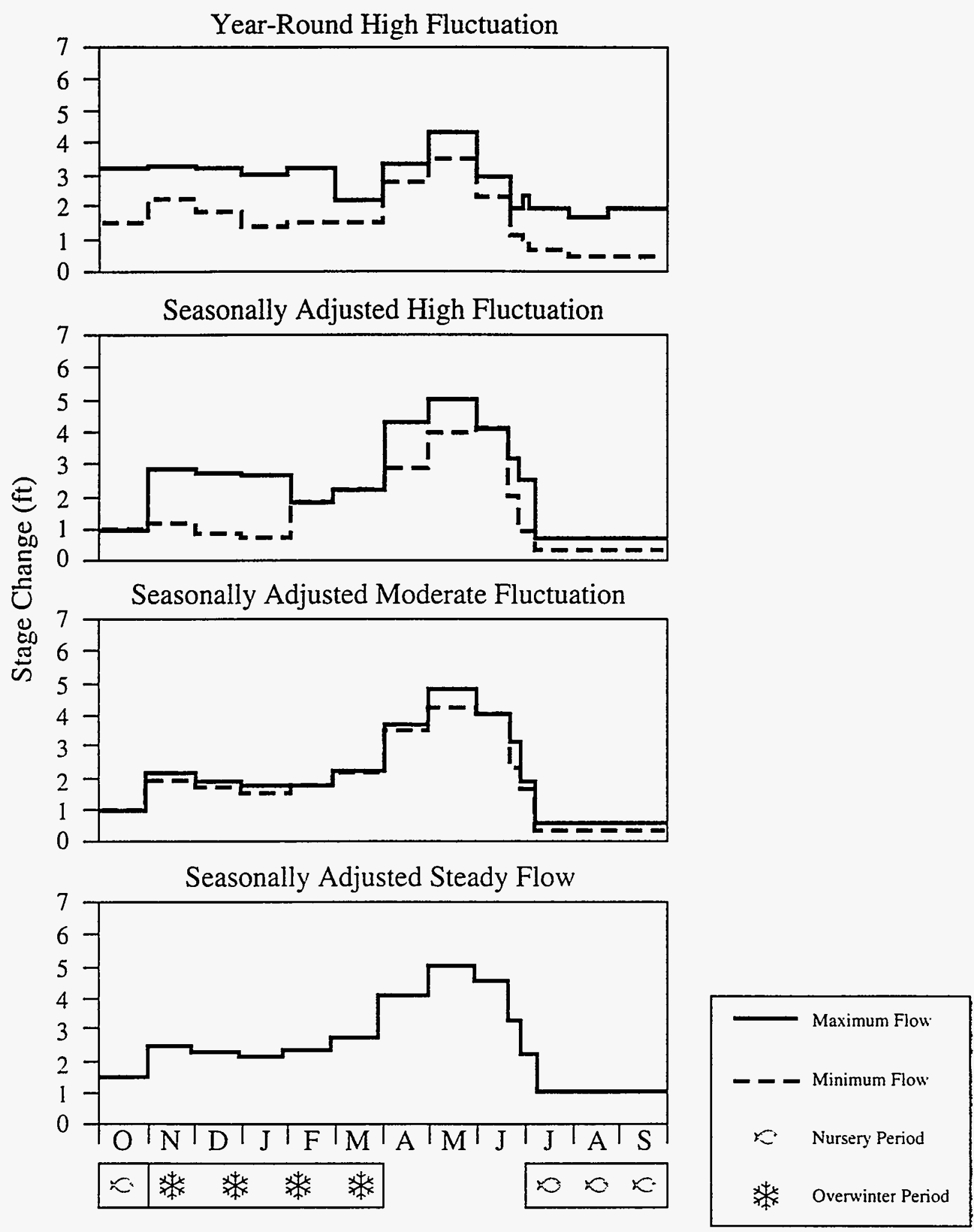

FIGURE 10 Minimum and Maximum River Stages at Jensen for the Flaming Gorge Dam Hydropower Operational Scenarios (Source: Adapted from Yin et al. 1995) 
scenarios because of daily fluctuations in the Yampa River inflow but not because of hydropower water releases. Stage changes induced by the Yampa River would occur under all scenarios. Under historical operations, the daily stage changes had a seasonal pattern similar to that predicted for the year-round high fluctuating flow scenario. However, because of a lower maximum dam release for historical operations $(4,200 \mathrm{cfs})$ compared with the yearround high fluctuating flow scenario $(4,700 \mathrm{cfs})$, the daily magnitude of the change is less (1.7 ft/d maximum). 


\section{ASSESSMENT OF IMPACTS}

\subsection{TROUT}

Concerns for trout in the Green River include maintenance of numbers, growth rates, condition factors, overwinter survival of stocked individuals, and natural reproduction near or above current levels. Impacts on these factors from each of the Flaming Gorge Dam operational scenarios were compared by considering the biological characteristics of trout and the probable changes from current conditions in food production, available spawning habitat, and overwinter survival under each scenario.

\subsubsection{Aquatic Food Base}

The assessment of impacts on the benthic food base assumed that the production of Cladophora and associated organisms would be highest in permanently wetted zones, intermediate in seasonally wetted zones, and lower in fluctuation zones with daily exposures of 1 to 12 hours. Areas with exposure times greater than 12 hours were considered unsuitable for sustaining a Cladophora-based community (Usher et al. 1987).

Approximately 23 acres per mile of permanently wetted zone would be available in the upper portion of the Green River for high production of the benthic food base under all operational scenarios (Figure 8). Under the year-round high fluctuating flow scenario, an additional 6 acres per mile would be available for low food production (in the fluctuation zone) only from November through February because daily exposure of the fluctuation zone would exceed 12 hours during other times of the year (Table 6).

Under the seasonally adjusted high fluctuating flow scenario, the fluctuation zone would be exposed for more than 12 hours per day, except from May through June 21 (Table 6). This period would probably be too short for any significant production by Cladophora and the benthic food base. The seasonally wetted zone present under this operational scenario would occur either for a very short period (June 1 to June 21) or during the winter (February and March) (Figure 8) when production would likely be low because of cold water temperatures. On the basis of these factors, it is predicted that production of the benthic food base would be slightly lower under the seasonally adjusted high fluctuating flow scenario than under the year-round high fluctuating flow scenario.

The seasonally adjusted moderate fluctuating flow scenario would lead to higher production of Cladophora and the benthic food base than the year-round high fluctuating flow scenario because an additional 3 acres per mile of seasonally wetted area would be present from November through June (Figure 8). Fluctuation zones under this scenario would be unsuitable for benthic food base production due to prolonged daily exposure periods (Table 6). Under seasonally adjusted steady flows, production of the benthic food base would be similar to that under seasonally adjusted moderate fluctuating flows because the seasonally wetted zone would be similar in magnitude and duration under both scenarios (Figure 8). 


\subsubsection{Spawning Habitat}

Successful reproduction of trout in the Green River is limited primarily by the availability of suitable spawning sites and successful hatching of eggs once they are spawned. Areas of the aquatic habitat that become exposed between the time that spawning begins and the emergence of young fish are of little value to reproducing trout and could reduce overall success of spawning by wasting the efforts of some spawning adults. Therefore, the critical period for successful reproduction extends from the spawning of eggs through the emergence of fry. This period extends from early October to late May for trout spawning in the fall (brown and rainbow trout) and from March through mid-July for trout spawning in the spring (rainbow and brook trout) (Modde et al. 1991). All the operational scenarios would provide the same amount of permanently wetted zone (Figure 8), and it was assumed that the number of available spawning sites in this zone would be similar. However, because the quality of a given redd site can be affected by water velocity and stage (water depth) at that site, some differences could occur in the number of higher quality sites between scenarios with different levels of flow. It was assumed that scenarios with lower flow fluctuations and lower daily stage changes would provide a more favorable environment for developing eggs than scenarios with higher flow fluctuations.

Both the year-round high fluctuating flow and the seasonally adjusted high fluctuating flow scenarios would limit the amount of potentially useable spawning area to the permanently wetted zone and would, therefore, provide similar reproduction potential for trout. The seasonally adjusted moderate fluctuating flow and seasonally adjusted steady flow scenarios would provide substantial and similar amounts of additional spawning areas for trout spawning in the fall and spring due to the prolonged presence of seasonally wetted zones (Figure 8) and the elimination of daily stage changes during portions of the late fall and early spring spawning periods (Figure 9); increased natural reproduction of brown, rainbow, and brook trout could result. Reproduction of trout could be greater under the seasonally adjusted steady flow scenario than under the seasonally adjusted moderate fluctuating flow scenario because daily fluctuations of about 2,000 cfs and stage changes of about $2.5 \mathrm{ft}$ would occur throughout portions of the spawning and egg development periods under the latter scenario (Figure 8).

\subsubsection{Overwinter Survival}

An important factor for maintaining the trout fishery downstream of Flaming Gorge Dam is the overwinter survival of fish that are stocked each spring. The current management practice is to stock hatchery-reared trout approximately $6 \mathrm{in}$. in length, with the goal of having those fish reach $12 \mathrm{in}$. by the end of the year. It has been demonstrated that trout smaller than $12 \mathrm{in}$. at the end of the year are more likely to die during the winter than larger trout (Modde et al. 1991). Therefore, increasing growth rates during the warmer period of the year could improve the proportion of trout that survive the winter. Under past operations, a large proportion of the stocked 6-in. trout successfully reached lengths of 12 in. or more. Another factor that could improve overwinter survival is the reduction of daily fluctuations in discharge and stage during winter months. Taking these two aspects of 
overwinter survival into account, the seasonally adjusted steady flow. scenario would be expected to provide the best overwinter survival, the seasonally adjusted moderate fluctuating flow scenario an intermediate level, and the year-round and seasonally adjusted high fluctuating flow scenarios the lowest levels (although similar to historical values).

The operational scenarios evaluated in this study feature one peak release each day. In the past, two peaks occasionally occurred within a single day, and these two daily peaks could affect overwinter survival of trout to a greater extent because of effects on energy expenditure. Although this study evaluated the effects of only a single daily peak release, the year-round high fluctuating flow scenario was assumed to be more detrimental to overwinter survival than any of the seasonally adjusted fluctuating flow scenarios with two daily peaks because the seasonally adjusted scenarios include prolonged periods of no daily stage flow or stage fluctuations in winter (Figures 4 and 9 , respectively). Thus, the effects on trout overwinter survival of a seasonally adjusted high fluctuating flow scenario with two daily peaks would be greater than the effects of a seasonally adjusted high fluctuating flow scenario with a single daily peak, but less than the effects of a year-round high fluctuating flow scenario.

\subsubsection{Growth and Condition}

The growth rates and condition factors for trout in the Green River are currently among the highest in the western United States, and only small (perhaps undetectable) differences would be likely to occur among the different operational scenarios. Generally, growth and condition could improve slightly as the amount of food resources increased. Therefore, the seasonally adjusted steady flow and seasonally adjusted moderate fluctuating flow scenarios would be expected to produce the fastest growth rates and the highest condition factors, whereas the seasonally adjusted high fluctuating flow scenario would yield the least potential improvement in growth and condition and the year-round high fluctuating flow scenario would produce an intermediate rate of growth.

\subsection{NATIVE AND ENDANGERED FISHES}

Use of the Green River above the Yampa River confluence by native and endangered fishes would remain limited under all operational scenarios because of releases of cold water from the dam, not because of hydropower operations. However, some increase in use by native and endangered fishes could occur under the seasonally adjusted operational scenarios in which daily flow and stage fluctuations would be reduced compared with historical operations or the year-round high fluctuating flow scenario. The primary concerns regarding: native and endangered fish species in the Green River below the Yampa River confluence are the reproduction, growth, condition, and recruitment of young fish and the overwinter survival of young and adult fish.

Because of the lack of information regarding the status and ecology of the bonytail in the Green River between the Yampa River confluence at Echo Park and Jensen, it was not. 
possible to identify potential impacts of the operational scenarios on this species. Because of the taxonomic similarity between the bonytail and humpback chub (Kaeding et al. 1986; USFWS 1992) and the general similarity in adult and juvenile habitats among the endangered Colorado River fishes, it was assumed that any positive or negative impacts incurred by the humpback chub under any of the operational scenarios would also be incurred by any bonytail that might still inhabit the river between Echo Park and Jensen. The USFWS used a similar assumption regarding the bonytail in its Biological Opinion for the operation of Flaming Gorge Dam (USFWS 1992).

\subsubsection{Reproduction}

None of the operational scenarios are expected to affect spawning by the humpback chub, which occurs in the Yampa River. However, under the year-round high fluctuating flow scenario, nearshore adult and juvenile habitats in winter would undergo daily fluctuations in river stage and flow. Although these changes would be relatively small at Jensen (less than $2 \mathrm{ft} / \mathrm{d}$ ), areas upstream of Jensen could experience greater daily stage changes, particularly in canyon reaches such as Whirlpool Canyon. Daily stage and flow fluctuations in winter have been suggested to stress overwintering fish (Valdez and Masslich 1989). The daily flow and stage fluctuations would be slightly greater under the year-round high fluctuating flow scenario than under historical operations. Thus, adult and juvenile humpback chubs could be stressed and exhibit a decreased overall condition entering the spawning season, which in turn could adversely affect reproduction.

Impacts of the operational scenarios on reproduction by the Colorado squawfish would be very similar to those identified for the humpback chub. None of the scenarios are expected to affect the two known spawning areas for this species. Migration cues in spring would be maintained under the year-round high fluctuating flow scenario by the natural spring peak of the Yampa River. Each of the seasonally adjusted operational scenarios includes a sustained spring peak with no daily fluctuations in flow, as required under the Biological Opinion (USFWS 1992). Daily fluctuations in water level under year-round high fluctuating flows might destabilize nearshore habitats for migrating adults in spring (USFWS 1992). It is not known if daily fluctuations affect migrating adults in any way, but such fluctuations could result in increased stress and reduced condition, which in turn could affect reproductive success. However, migrating adults successfully migrated to and spawned in the Yampa River under historical operations (USFWS 1991a).

Impacts of the operational scenarios on reproduction in the razorback sucker would be similar to the impacts identified for the humpback chub and Colorado squawfish. None of the operational scenarios would be expected to affect access to spawning areas in the Yampa River or in the Green River below Jensen. Migration cues in spring are currently maintained under historical operations by the natural spring peak of the Yampa River and would continue under the year-round high fluctuating flow scenario. Each of the seasonally adjusted scenarios includes a sustained spring peak in dam releases that is similar to the 
historical, pre-dam hydrograph. Thus, migration cues could be strengthened by these scenarios and thus increase reproduction (but not necessarily recruitment) by the razorback sucker.

Overbank flooding of historically flooded bottomlands during spring runoff is considered to be beneficial to adult razorback suckers and important for dispersal and rearing of young (USFWS 1992). Because of the sustained spring peak in dam releases, overbank flooding would be greater under each of the seasonally adjusted operational scenarios than under the year-round high fluctuating flow scenario or historical operations. Because the magnitude and duration of the spring peak would be identical among the seasonally adjusted scenarios, no differences are anticipated among these scenarios in the amount of historical bottomland that would be flooded in spring.

\subsubsection{Nursery Habitat Stability, Food Resource Production, and Recruitment}

Each of the seasonally adjusted operational scenarios would include high sustained spring flows. Because of these high sustained spring releases, backwater nursery habitats would be more thoroughly prepared under these scenarios than under the year-round high fluctuating flow scenario or historical operations.

The year-round high fluctuating flow scenario would result in the greatest daily change in backwater area and stage of all the scenarios, whereas the seasonally adjusted steady flow scenario would produce the least change. Relative to the year-round high fluctuating flow scenario, the stability of backwater nursery habitats would be increased under each of the seasonally adjusted scenarios. Backwater stability would be lowest under the seasonally adjusted high fluctuating flow scenario and highest under the seasonally adjusted steady flow scenario. However, the magnitude of the difference during the nursery period among the three seasonally adjusted scenarios would be relatively small. Daily stage changes at Jensen would differ by less than $0.5 \mathrm{ft} / \mathrm{d}$ between the high fluctuating flow and steady flow scenarios and would differ by less than $0.2 \mathrm{ft} / \mathrm{d}$ (less than $3 \mathrm{in} . / \mathrm{d}$ difference) in mid summer and early autumn between the seasonally adjusted moderate fluctuating flow and seasonally adjusted steady flow scenarios.

Among the seasonally adjusted scenarios, predicted changes in backwater area at Jensen would be greatest for the high fluctuating flow scenario (about $7,000 \mathrm{ft}^{2} / \mathrm{mi}$ ) for most of the nursery period and very small (less than $2,000 \mathrm{ft}^{2} / \mathrm{mi}$ ) under the moderate fluctuating flow and steady flow scenarios. Greater differences in habitat stability could occur in summer and autumn as a result of the natural daily variation in flow of the Yampa River, independent of hydropower operations at Flaming Gorge Dam. No fluctuations in backwater area would be expected in October among any of the seasonally adjusted scenarios.

On the basis of the predicted daily changes in backwater area and stage, production of the food base in backwater nursery habitats would be lowest under the year-round high fluctuating flow scenario and highest under the seasonally adjusted steady flow and seasonally adjusted moderate fluctuating flow scenarios. 
Because the growth and condition of native and endangered fishes in the Green River depends in large part upon the stability of backwater nursery habitats, assumed reductions in daily fluctuations of backwater area and stage would be expected to increase survival and growth, and thus recruitment, of native and endangered fishes. The year-round high fluctuating flow and seasonally adjusted high fluctuating flow scenarios would produce the least stable conditions in backwaters during the nursery period and thus potentially reduced recruitment. Because of increased backwater stability, the seasonally adjusted moderate fluctuating flow and seasonally adjusted steady flow scenarios would provide the most potential for increased recruitment of native and endangered fishes.

The high degree of stability of backwater habitats that could occur under the seasonally adjusted scenarios has the potential to increase recruitment of the razorback sucker. However, the survival and recruitment of razorback sucker larvae in the Green River is extremely low. Predation by introduced species has been suggested to be a major factor affecting recruitment of the razorback sucker (Minckley 1991; Minckley et al. 1991). Evidence of the important role of predation in the loss of razorback sucker larvae comes from a variety of studies in which larvae survive and grow in the absence of predators but very rapidly disappear when predators are introduced (Minckley 1991). Species that may prey on razorback sucker eggs and larvae include the channel catfish, green sunfish, carp, and bluegill. In the absence of any measures to prevent introduced species from inhabiting razorback sucker nursery habitats and mitigate impacts of predation by introduced species, it is doubtful if razorback sucker recruitment would benefit substantially from the increased stability of nursery habitats. However, because of the overall absence of any successful recruitment to the razorback sucker population over the last 20 to 30 years, even a very small increase in successful recruitment would be of great value to this species.

\subsubsection{Overwinter Survival}

Winter fluctuations in flow have been observed to increase the activity of some Green River fishes (Valdez and Masslich 1989) and may have the potential to cause increased overwinter mortality of endangered fishes. Ice breakup, jams, and shoreline scouring resulting from fluctuating flows in winter have also been suggested to be undesirable for overwintering endangered fishes, whereas stable flows in winter may reduce stress and thus increase overwinter survival (USFWS 1992). The degree to which fluctuating flows in winter, ice breakup, and shoreline scouring may affect endangered fish is not well understood. The Biological Opinion includes a 5-year research program that will collect additional data on the winter flow needs for endangered fishes, and these data will be used for the refinement of winter flow recommendations (USFWS 1992).

The greatest fluctuations in winter flow and stage would occur under the seasonally adjusted high fluctuating flow scenario, and fluctuations would be only slightly lower under the year-round high fluctuating flow scenario. Under these conditions, the potential for ice breakup and scouring might be increased over historical operations. Thus, these scenarios are expected to have the highest potential for overwinter mortality of native and endangered 
fishes. The potential for overwinter mortality would be reduced for the seasonally adjusted moderate fluctuating flow scenario and lowest for the seasonally adjusted steady flow scenario.

\subsubsection{Potential Responses of Introduced Fish}

Stabilization of nursery and other habitats in summer might enhance populations of introduced species. Competition with, and predation by, introduced species have been suggested as major factors affecting the status of the humpback chub and other endangered species (Minckley 1991; USFWS 1992). Increased stability of aquatic habitats might result in increased survival and recruitment of introduced species, thereby negating any benefits accrued by the native and endangered fishes under any of the operational scenarios. The potential for increasing populations of introduced species, and thus potential competition and predation, would be greatest under the seasonally adjusted moderate fluctuating flow and steady flow scenarios, and competition or predation could be increased over current levels as a result of steady flows. The potential for increasing populations of introduced species would be lowest under year-round high fluctuating flows and intermediate under seasonally adjusted high fluctuating flows. 


\section{CONCLUSIONS}

The amount of food and habitat available to trout during much of the growing season is restricted primarily by the size of the permanently wetted zone, so substantial increases in the number of trout within the tailwater area would be likely to result in a decrease in growth rates and condition of trout present during this period. Because only slight increases in food would be anticipated under scenarios providing reduced fluctuations (seasonally adjusted moderate fluctuating flow and seasonally adjusted steady flow), increases in reproduction could be detrimental to the fishery unless changes occurred in the number of fish stocked annually. If organizations responsible for fishery management of Flaming Gorge Dam tailwaters responded to increases in natural reproduction by decreasing stocking efforts, thereby maintaining similar densities of trout, slight improvements in growth and condition of trout could be realized. Slight improvements in growth, condition, and overwinter survival - together with potentially large increases in the success of natural reproduction under the seasonally adjusted moderate fluctuating flow or seasonally adjusted steady flow scenarios - could thus allow the agencies responsible for managing the trout fishery to stock fewer and/or smaller trout.

On the basis of anticipated impacts on nursery habitats, recruitment, and overwinter survival, the seasonally adjusted moderate fluctuating flow and seasonally adjusted steady flow scenarios would provide the most benefit to native and endangered fishes. The seasonally adjusted high fluctuating flow scenario would increase nursery habitat stability and, thus, potentially recruitment to a level similar to that identified for the other seasonally adjusted scenarios, but this scenario would also have a higher potential for overwinter mortality. The year-round high fluctuating flow scenario would have the greatest adverse impacts on native and endangered fishes. Under this scenario, backwater stability would be the lowest among all the scenarios and would be also be reduced compared with historical operations. Similarly, because of the greater maximum daily changes in winter flow and stage, native and endangered fishes would have a greater potential overwinter mortality under the year-round high fluctuating flow and seasonally adjusted high fluctuating flow scenarios than under historical operations or under the seasonally adjusted moderate fluctuating flow or steady flow scenarios.

Potential adverse impacts of introduced fishes on native and endangered fishes could be greater under the seasonally adjusted scenarios. If introduced fishes benefit from the same factors as native fish species, introduced fish populations could increase, and competition and predation from introduced fishes species could reduce any positive benefits anticipated for native species. 


\section{REFERENCES}

American Fisheries Society, 1991, Common and Scientific Names of Fishes from the United States and Canada, American Fisheries Society Special Publication 20, Bethesda, Maryland.

Annear, T.C., 1980, A Characterization of Yampa and Green River Ecosystems, M.Sc. Thesis, Utah State University, Logan, Utah.

Bestgen, KR., 1990, Status Review of the Razorback Sucker, Xyrauchen texanus, Contribution 44, Larval Fish Laboratory, Colorado State University, Fort Collins, Colo., Oct.

Carothers, S.W., and B.T. Brown, 1991, The Colorado River through Grand Canyon Natural History and Human Change, The University of Arizona Press, Tucson, Ariz.

Gosse, J.C., 1982, Microhabitat of Rainbow and Cutthroat Trout in the Green River below Flaming Gorge Dam, Vol. 1: Narrative Report, prepared by Aqua-Tech Biological Consulting Firm, Logan, Utah, for Utah Division of Wildlife Resources, Salt Lake City, Utah.

Grabowski, S.J., and S.D. Hiebert, 1989, Some Aspects of Trophic Interactions in Selected Backwaters and the Main Channel of the Green River, Utah, 1987-1988, Special Report, U.S. Bureau of Reclamation, Research and Laboratory Services Division, Denver, Colo., July.

Haines, G., and H.M. Tyus, 1990, "Fish Associations and Environmental Variables in Age-0 Colorado Squawfish Habitats, Green River, Utah," Journal of Freshwater Ecology 5(4):427435.

Holden, P.B., 1991, "Ghosts of the Green River: Impacts of Green River Poisoning on Management of Native Fishes," in Battle against Extinction: Native Fish Management in the American West, W.L. Minckley and J.E. Deacon (editors), University of Arizona Press, Tucson, Ariz.

Holden, P.B., and L.W. Crist, 1981, Documentation of Changes in the Macroinvertebrate and Fish Populations in the Green River Due to Inlet Modification of Flaming Gorge Dam, Final Report, No. PR-16-5, BIO/WEST, Inc., Logan, Utah, March.

Johnson, C.D., 1992, letter from C.D. Johnson (Assistant Field Supervisor, U.S. Fish and Wildlife Service, Salt Lake City, Utah) to I. Hlohowskyj (Argonne National Laboratory, Argonne, Ill.), March 30.

Johnson, J.E., et al., 1987, Flaming Gorge Tailwater Fisheries Investigations: Growth, Survival and Microhabitat Selection in the Green River of Utah, 1978-1982, Publication No. 87-13, Utah Division of Wildlife Resources, Salt Lake City, Utah. 
Kaeding, L.R., et al., 1986, "Recent Capture of a Bonytail (Gila elegans) and Observations on this Nearly Extinct Cyprimid from the Colorado River," Capeia 1986(4):1021-1023.

Karp, C.A., and H.M. Tyus, 1990, "Humpback Chub (Gila cypha) in the Yampa and Green Rivers, Dinosaur National Monument, with Observations on Roundtail Chub (G. robusta) and Other Sympatric Fishes," Great Basin Naturalist 50(3):257-264.

Lanigan, S.H., and H.M. Tyus, 1989, "Population Size and Status of the Razorback Sucker in the Green River Basin, Utah and Colorado," North American Journal of Fisheries Management 9:68-73.

Minckley, W.L., 1991, "Native Fishes of the Grand Canyon Region: An Obituary?," in Colorado River Ecology and Dam Management, Proceedings of a Symposium, May 24-25, 1990, Santa Fe, New Mexico, National Academy Press, Washington, D.C., pp. 124-177.

Minckley, W.L., et al., 1991, "Management toward Recovery of the Razorback Sucker," in Battle against Extinction: Native Fish Management in the American West, W.L. Minckley and J.E. Deacon (editors), University of Arizona Press, Tucson, Ariz., pp. 303-357.

Modde, T., et al., 1991, Evaluation of Factors Influencing Population Characteristics and Habitat Utilization of Trout in the Flaming Gorge Tailwater, 1987-1989, Publication No. 91-10, Flaming Gorge Tailwater Studies, Utah Division of Wildlife Resources, Salt Lake City, Utah.

Neale, C.M.U., 1992, An Airborne Multispectral Video/Radiometer Remote Sensing System for Natural Resource Monitoring, Proceedings of the 13th Biennial Workshop on Color Aerial Photography and Videography in the Plant Sciences, American Society of Photogrammetry and Remote Sensing, Falls Church, Va.

Pucherelli, M.J., et al., 1990, Mapping Backwater Habitat on the Green River as Related to the Operation of Flaming Gorge Dam and Using Remote Sensing and GIS, U.S. Bureau of Reclamation, Applied Sciences Branch, Research and Laboratory Services Division, Denver, Colo., Sept.

Schnurr, P.M., 1992, "Wildlife Resource Information System Scenario for Bonytail," letter from P.M. Schnurr (Colorado Department of Natural Resources, Division of Wildlife, Denver, Colo.) to R.A. Van Lonkhuyzen (Argonne National Laboratory, Argonne, Ill.), Oct. 29.

Smith, G.R., and R.G. Green, 1991, Flaming Gorge Consolidated Hydrology Report, U.S. Fish and Wildlife Service, Division of Water Resources, Region 6, Denver, Colo., Jan.

Snider, M.A., et al., 1994, "Use of Aerial Videography to Evaluate the Effects of Flaming Gorge Dam Operations on Natural Resources of the Green River," pp. 145-153 in Color Aerial Photography and Videography for Resource Monitoring, Proceedings of the 14th Biennial Workshop, Logan, Utah, 25-29 May 1993, American Society for Photogrammetry and Remote Sensing, Bethesda, Md. 
Tyus, H.M., 1987, "Distribution, Reproduction, and Habitat Use of the Razorback Sucker in the Green River, Utah, 1979-1986," Transactions of the American Fisheries Society 116:111-116.

Tyus, H.M., 1990, "Potamodromy and Reproduction of Colorado Squawfish in the Green River Basin, Colorado and Utah," Transactions of the American Fisheries Society 119:1035-1047.

Tyus, H.M., 1991, "Ecology and Management of Colorado Squawfish," in Battle against Extinction: Native Fish Management in the American West, W.L. Minckley and J.E. Deacon (editors), University of Arizona Press, Tucson, Ariz., pp. 379-402.

Tyus, H.M., and J.M. Beard, 1990, "Esox lucius (Esocidae) and Stizostedion vitreum (Percidae) in the Green River Basin, Colorado and Utah," Great Basin Naturalist 50(1):33-39.

Tyus, H.M., and G.B. Haines, 1991, "Distribution, Habitat Use, and Growth of Age-0 Colorado Squawfish in the Green River Basin, Colorado and Utah," Transactions of the American Fisheries Society 120:79-89.

Tyus, H.M., and C.A. Karp, 1990, "Spawning Movements of Razorback Sucker, Xyrauchen texanus, in the Green River Basin of Colorado and Utah," The Southwestern Naturalist 35(4):427-433.

Tyus, H.M., and C.A. Karp, 1991, Habitat Use and Streamflow Needs of Rare and Endangered Fishes in the Green River, Utah, Final Report, U.S. Fish and Wildlife Service, Flaming Gorge Studies Program, Colorado River Project Office, Vernal, Utah, July 31.

Tyus, H.M., and N.J. Nikirk, 1990, "Abundance, Growth, and Diet of Channel Catfish, Ictalurus punctatus, in the Green and Yampa Rivers, Colorado and Utah," Southwestern Naturalist 35(2):188-198.

Tyus, H.M., et al., 1982, "Fishes of the Upper Colorado River Basin: Distribution, Abundance, and Status," in Fishes of the Upper Colorado River System: Present and Future, W.H. Miller, et al. (editors), American Fisheries Society, Western Division, Bethesda, Md., Dec., pp. 12-70.

U.S. Army Corps of Engineers, 1987, User Manual: SSARR Model, Streamflow Synthesis and Reservoir Regulation, North Pacific Division, Portland, Ore.

USFWS: see U.S. Fish and Wildlife Service.

U.S. Fish and Wildlife Service, 1990a, Bonytail Chub Recovery Program, U.S. Fish and Wildlife Service, Denver, Colo., Sept. 4.

U.S. Fish and Wildlife Service, 1990b, Humpback Chub Recovery Plan, U.S. Fish and Wildlife Service, Denver, Colo., Sept. 19. 
U.S. Fish and Wildlife Service, 1991a, Colorado Squawfish Recovery Plan, U.S. Fish and Wildlife Service, Denver, Colo., Aug. 6.

U.S. Fish and Wildlife Service, 1991b, "Endangered and Threatened Wildlife and Plants; the Razorback Sucker (Xyrauchen texanus) Determined to be an Endangered Species (50 CFR Part 17)," Federal Register 56(205):54957-54967, Oct. 23.

U.S. Fish and Wildlife Service, 1992, Final Biological Opinion for the Operation of Flaming Gorge Dam, Mountain-Prairie Region, Denver, Colo., Nov. 25.

U.S. Fish and Wildlife Service, 1993, "Endangered and Threatened Wildlife and Plants: Proposed Determination of Critical Habitat for the Colorado River Endangered Fishes: Razorback Sucker, Colorado Squawfish, Humpback Chub, and Bonytail Chub (50 CFR Part 17), Federal Register 58(18):6578-6597, Jan. 29.

U.S. Fish and Wildlife Service, 1994, "Endangered and Threatened Wildlife and Plants: Determination of Critical Habitat for the Colorado River Endangered Fishes: Razorback Sucker, Colorado Squawfish, Humpback Chub, and Bonytail Chub; Correction (50 CFR Part 17), Federal Register 59(54):13374, March 21.

Usher, H.D., et al.. 1987, Cladophora glomerata and its Diatom Epiphytes in the Colorado River Through Glen and Grand Canyons: Distribution and Desiccation Tolerance, prepared for the Bureau of Reclamation, Upper Colorado Region, Salt Lake City, Utah, Sept.

Valdez, R.A., and W.J. Masslich, 1989, Winter Habitat Study of Endangered Fish, Green River: Wintertime Movement and Habitat of Adult Colorado Squawfish and Razorback Suckers, Report No. 136-2, BIO/WEST, Inc., Logan, Utah, April.

Yin, S.C.L., et al., 1995, Effects of Flaming Gorge Dam Hydropower Operations on Flow and Stage in the Green River, Utah and Colorado, ANL/EAD/TM-4, Argonne National Laboratory, Argonne, Ill., May. 